\title{
Simulating aerosol-radiation-cloud feedbacks on meteorology and air quality over eastern China under severe haze conditions in winter
}

\author{
B. Zhang ${ }^{1,2}$, Y. Wang ${ }^{1,3,4}$, and J. Hao ${ }^{2}$ \\ ${ }^{1}$ Ministry of Education Key Laboratory for Earth System Modeling, Center for Earth System Science, \\ Institute for Global Change Studies, Tsinghua University, Beijing, 100084, China \\ ${ }^{2}$ School of Environment, Tsinghua University, Beijing, 100084, China \\ ${ }^{3}$ Department of Marine Sciences, Texas A\&M University Galveston Campus, Galveston, TX 77553, USA \\ ${ }^{4}$ Department of Atmospheric Sciences, Texas A\&M University, College Station, TX 77843, USA
}

Correspondence to: Y. Wang (yxw@ mail.tsinghua.edu.cn)

Received: 21 September 2014 - Published in Atmos. Chem. Phys. Discuss.: 17 October 2014

Revised: 18 January 2015 - Accepted: 1 February 2015 - Published: 4 March 2015

\begin{abstract}
The aerosol-radiation-cloud feedbacks on meteorology and air quality over eastern China under severe winter haze conditions in January 2013 are simulated using the fully coupled online Weather Research and Forecasting/Chemistry (WRF-Chem) model. Three simulation scenarios including different aerosol configurations are undertaken to distinguish the aerosol's radiative (direct and semi-direct) and indirect effects. Simulated spatial and temporal variations of $\mathrm{PM}_{2.5}$ are generally consistent with surface observations, with a mean bias of $-18.9 \mu \mathrm{g} \mathrm{m}^{-3}(-15.0 \%)$ averaged over $71 \mathrm{big}$ cities in China. Comparisons between different scenarios reveal that aerosol radiative effects (direct effect and semidirect effects) result in reductions of downward shortwave flux at the surface, $2 \mathrm{~m}$ temperature, $10 \mathrm{~m}$ wind speed and planetary boundary layer (PBL) height by up to $84.0 \mathrm{~W} \mathrm{~m}^{-2}$, $3.2^{\circ} \mathrm{C}, 0.8 \mathrm{~m} \mathrm{~s}^{-1}$, and $268 \mathrm{~m}$, respectively. The simulated impact of the aerosol indirect effects is comparatively smaller. Through reducing the PBL height and stabilizing lower atmosphere, the aerosol effects lead to increases in surface concentrations of primary pollutants $\left(\mathrm{CO}\right.$ and $\left.\mathrm{SO}_{2}\right)$. Surface $\mathrm{O}_{3}$ mixing ratio is reduced by up to $6.9 \mathrm{ppb}$ (parts per billion) due to reduced incoming solar radiation and lower temperature, while the aerosol feedbacks on $\mathrm{PM}_{2.5}$ mass concentrations show some spatial variations. Comparisons of model results with observations show that inclusion of aerosol feedbacks in the model significantly improves model performance in simulating meteorological variables and improves simulations of $\mathrm{PM}_{2.5}$ temporal distributions over the
\end{abstract}

North China Plain, the Yangtze River delta, the Pearl River delta, and central China. Although the aerosol-radiationcloud feedbacks on aerosol mass concentrations are subject to uncertainties, this work demonstrates the significance of aerosol-radiation-cloud feedbacks for real-time air quality forecasting under haze conditions.

\section{Introduction}

Atmospheric aerosols are known to play a key role in the earth climate system. They absorb and scatter incoming solar radiation, referred to as the direct effect (Hansen et al., 1997). They also alter cloud properties by serving as cloud condensation nuclei (CCN), which is known as the indirect effect (Albrecht, 1989; Twomey, 1977; Rosenfeld et al., 2008). Absorbing aerosols in and under the cloud may heat the atmosphere, leading to evaporation of clouds (semidirect effect) (Charlson and Pilat, 1969). It is of increasing interest to understand and quantify the complex impacts of aerosols on meteorology and air quality. The coupled "online" meteorology-air quality strategy with aerosol feedbacks is essential for real-time air quality forecasting using 3D models. Negligence of aerosol feedbacks may lead to poor performance of the next hour's meteorology and air quality forecasting, especially for high aerosol loading regions (Grell and Baklanov, 2011; Zhang et al., 2012). 
Models simulating the direct, indirect, and semi-direct effects of aerosols on meteorology and chemistry need to couple aerosols with physical and chemical processes. The chemistry version of the Weather Research and Forecasting (WRF-Chem) model (Grell et al., 2005) is a state-of-the-art mesoscale "online" atmospheric model, in which the chemical processes and meteorology are simulated simultaneously. This design makes WRF-Chem capable of simulating aerosol feedbacks on various atmospheric processes. Several studies employing WRF-Chem reveal that aerosols reduce downward solar radiation reaching the ground, inhibit convection, reduce the PBL (planetary boundary layer) and, hence, make the lower atmosphere more stable (Fan et al., 2008; Forkel et al., 2012; Zhang et al., 2010). WRF-Chem results also indicate that aerosols can modify atmospheric circulation systems, resulting in changes in monsoon strength, precipitation distribution, and midlatitude cyclones (Zhao et al., 2011, 2012).

In January 2013, several severe and long-lasting haze episodes occurred in eastern China (Fig. 1). Monthly mean mass concentrations of fine particulate matter $\left(\mathrm{PM}_{2.5}\right)$ exceeded $200 \mathrm{\mu g} \mathrm{m}^{-3}$ in some cities in the North China Plain. Meteorological conditions and chemical components of $\mathrm{PM}_{2.5}$ during this month have been investigated by a number of studies in order to understand the chemical characteristics and formation mechanism of severe winter haze episodes (Bi et al., 2014; Che et al., 2014; K. Huang, et al., 2014; Sun et al., 2014; L. T. Wang et al., 2014; Y. S. Wang et al., 2014; Y. X. Wang et al., 2014; Z. F. Wang et al., 2014; J. K. Zhang et al., 2014). Meanwhile, such high levels of PM concentrations are expected to exert impacts on meteorological conditions through the aerosol-radiation-cloud interactions. Few of the current air quality forecasting systems for China include aerosol-meteorology interactions. The significance of this effect and the extent to which it feedbacks on air quality remains to be uncertain and needs to be quantified for better future forecasting of air quality in China (Wang et al., 2013; Y. Zhang et al., 2014; Z. F. Wang et al., 2014).

In this work, the fully coupled online WRF-Chem model is employed to simulate the complex interactions between aerosols and meteorology and to characterize and quantify the influences of aerosol feedbacks on meteorology and air quality under severe winter haze conditions in January 2013 over eastern China. The aerosol direct, indirect and semidirect effects are all included in the WRF-Chem simulation and analyzed separately. The WRF-Chem model configuration, scenarios setup, and observation data are described in Sect. 2. Section 3 evaluates the model performance in simulating meteorology and air quality. In Sect. 4, the aerosol feedbacks on meteorology and air quality are analyzed and discussed. Section 5 investigates the effects of including aerosol feedbacks on the model performance. The concluding remarks are given in Sect. 6.

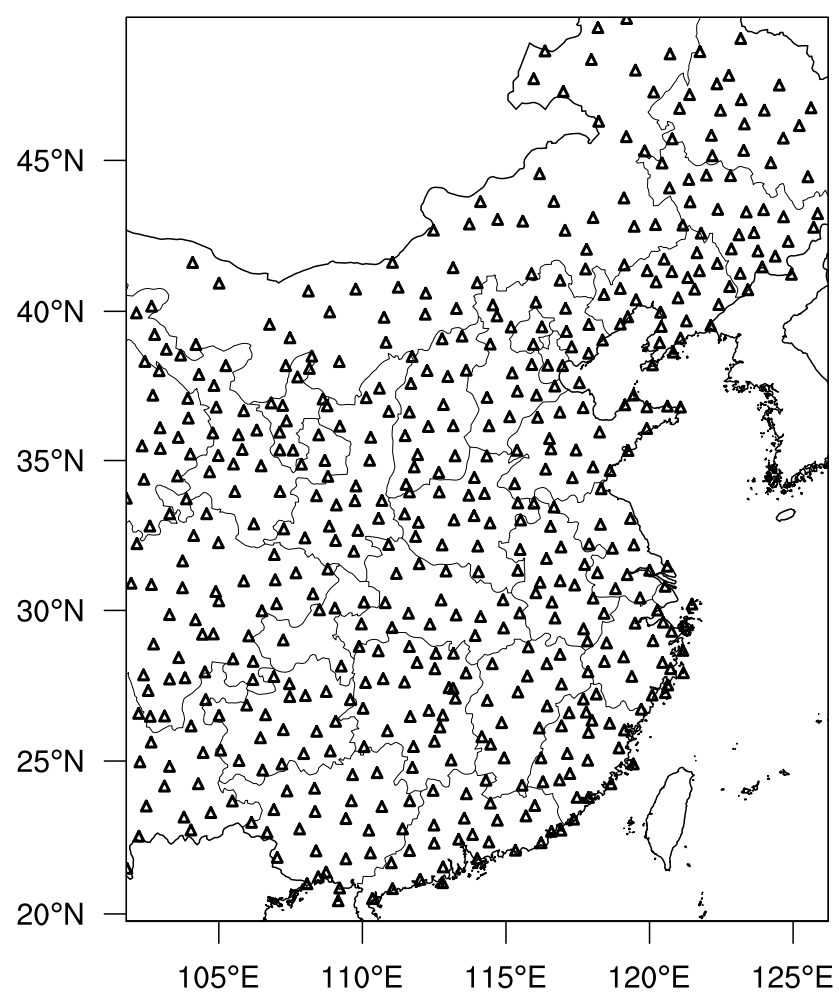

Figure 1. WRF-Chem modeling domain with grid resolution of $27 \mathrm{~km}$. The domain covers eastern parts of China. The triangles indicate the location of 523 meteorology stations used for evaluations in this work

\section{Model and observations description}

\subsection{WRF-Chem model and scenarios setup}

The WRF model is a state-of-the-art mesoscale nonhydrostatic model and allows for many different choices for physical parameterizations (http://www.wrf-model.org/). WRFChem is a chemical version of WRF that simultaneously simulates meteorological and chemical components. The version 3.3 of WRF-Chem released on 6 April 2011 is used in this study. A more detailed description of the model can be found in previous studies (Grell et al., 2005; Fast et al., 2006; Chapman et al., 2009).

The main physical options selected in this study include the Goddard shortwave radiation scheme coupled with aerosol direct effects (Chou et al., 1998), the Rapid Radiative Transfer Model (RRTM) longwave radiation scheme (Mlawer et al., 1997), the Noah Land Surface Model (Chen and Dudhia, 2001), the Yonsei University (YSU) boundary layer scheme (Hong et al., 2006), the Lin microphysics scheme coupled with aerosol indirect effects (Lin et al., 1983), and the Grell-Devenyi cumulus parameterization scheme (Grell and Dévényi, 2002).

For the aerosol direct effect, aerosol optical properties such as extinction, single scattering albedo, and asymmetry 
factor are calculated as a function of wavelength and threedimensional position, and then transferred to the Goddard shortwave scheme. Mie theory is used to estimate the extinction efficiency. In this study, refractive indices are calculated based upon a volume-averaging approximation. The first and second indirect effects are implemented in the model (Gustafson et al., 2007; Chapman et al., 2009). Activated aerosols serving as $\mathrm{CCN}$ are coupled with cloud microphysics. Activation of aerosols follows the method of Ghan and Easter (2006), which is derived from Abdul-Razzak and Ghan (2002). Through this coupling, aerosols alter cloud droplet number and cloud radiative properties, while aqueous processes and wet scavenging also affect aerosols. In the model, aerosols change vertical profiles of meteorological variables by absorbing and scattering solar radiation, and further alter cumulus parameterization. When indirect effects are included, a more comprehensive in- and belowcloud aerosol wet removal module following the method of Easter et al. (2004) is employed.

The Carbon Bond Mechanism version Z (CBMZ) (Zaveri and Peters, 1999) is used as the gas-phase chemistry scheme. The Model for Simulating Aerosol Interactions and Chemistry (MOSAIC) (Zaveri et al., 2008) is applied as aerosol module. MOSAIC simulates aerosol species including sulfate, methanesulfonate, nitrate, ammonium, chloride, carbonate, sodium, calcium, black carbon (BC), organic carbon (OC), and other unspecified inorganic matter (OIN). Secondary organic aerosols (SOA) are not included in the version of MOSAIC used in this study. Section 3.3 discusses the impact of SOA on our analysis by replacing MOSAIC with the Modal Aerosol Dynamics Model for Europe (MADE) (Ackermann et al., 1998) and with the secondary organic aerosol model (SORGAM) (Schell et al., 2001) (referred to as MADE/SORGAM). MOSAIC in WRF-Chem uses a sectional approach to represent particle size distribution. In this study, four size bins $(0.039-0.156,0.156-0.625,0.625-2.5$, and $2.5-10.0 \mu \mathrm{m}$ dry diameter) are employed, and aerosols are assumed to be internally mixed within each bin.

The simulated time period is the whole month of January 2013. Figure 1 illustrates the model domain, which covers eastern China $\left(19^{\circ}-51^{\circ} \mathrm{N}, 96^{\circ}-132^{\circ} \mathrm{E}\right)$ and has a horizontal resolution of $27 \mathrm{~km} \times 27 \mathrm{~km}$. There are 28 vertical levels extending from the surface to $50 \mathrm{hPa}$. The initial and boundary conditions for WRF are provided by the 6-hourly $1^{\circ} \times 1^{\circ}$ National Centers for Environmental Prediction (NCEP) Final Analysis (FNL). Chemical boundary conditions are provided by MOZART (Model for Ozone And Related chemical Tracers) simulations (Emmons et al., 2010). In the initial spin-up process, the model is run with NCEP meteorological and MOZART chemical conditions for $48 \mathrm{~h}$, which are sufficient for the meteorological and chemical variables to reach equilibrium. Considering both accuracy and efficiency, the model's meteorology is re-initialized every 5 days based on NCEP, while chemistry adopts the previous state.
Table 1. Summary of three simulated scenarios.

\begin{tabular}{ll}
\hline Case name & Characteristics \\
\hline BASE & With all aerosol feedbacks \\
RAD & Only with aerosol direct and semi-direct effects \\
EMP & Without any aerosol feedbacks \\
\hline
\end{tabular}

In order to investigate the impact of aerosol feedbacks on meteorology and air quality, three WRF-Chem simulation scenarios are performed and compared. The first is the baseline scenario (BASE), including all aerosol effects on meteorology (i.e., direct, indirect, and semi-direct). The second scenario (RAD) focuses on the radiative effects by excluding aerosol indirect effects from the BASE scenario. The third scenario (EMP) does not contain any aerosol effects on meteorology. Aerosol radiative properties are connected with the shortwave radiation scheme in the BASE and RAD scenarios but not in the EMP scenario. Cloud droplet number is prescribed to be $1.0 \times 10^{8}$ particles per $\mathrm{kg}$ of air in EMP and RAD, while it is calculated based on aerosol activation in BASE. Other than the differences in aerosols effects, the three scenarios are identical in input data (e.g., emissions and boundary conditions) and model setup. The difference between BASE and EMP (i.e., BASE - EMP) is used to investigate the impact of total aerosol feedbacks, while the difference between BASE and RAD (i.e., BASE - RAD) and that between RAD and EMP (i.e., RAD - EMP) represent the influence of aerosol indirect effects and radiative (both direct and semi-direct) effects, respectively. Table 1 summarizes the characteristics of the three scenarios.

\subsection{Emissions}

Anthropogenic emissions are taken from the Multiresolution Emission Inventory of China (MEIC) (http://www. meicmodel.org/), which provides emissions of sulfur dioxide $\left(\mathrm{SO}_{2}\right)$, nitrogen oxides $\left(\mathrm{NO}_{\mathrm{x}}\right)$, carbon monoxide $(\mathrm{CO})$, ammonia $\left(\mathrm{NH}_{3}\right), \mathrm{BC}, \mathrm{OC}, \mathrm{PM}_{10}, \mathrm{PM}_{2.5}$, and non-methane volatile organic compounds (NMVOCs) for China for the year 2010. $\mathrm{NO}_{\mathrm{x}}$ emissions contain $90 \%$ of $\mathrm{NO}_{2}$ and $10 \%$ of NO by mole fraction. PM emissions are assumed to be split into $20 \%$ in nuclei mode and $80 \%$ in accumulation mode, according to the recommended construction of anthropogenic emissions inventory in WRF-Chem user's guide.

Biogenic emissions are calculated online in the model based on the Model of Emissions of Gases and Aerosols from Nature (MEGAN) inventory (Guenther et al., 2006). Dust is included in the simulations while sea salt or dimethylsulfide (DMS) are not, and their impacts are expected to be small over eastern China in winter. 

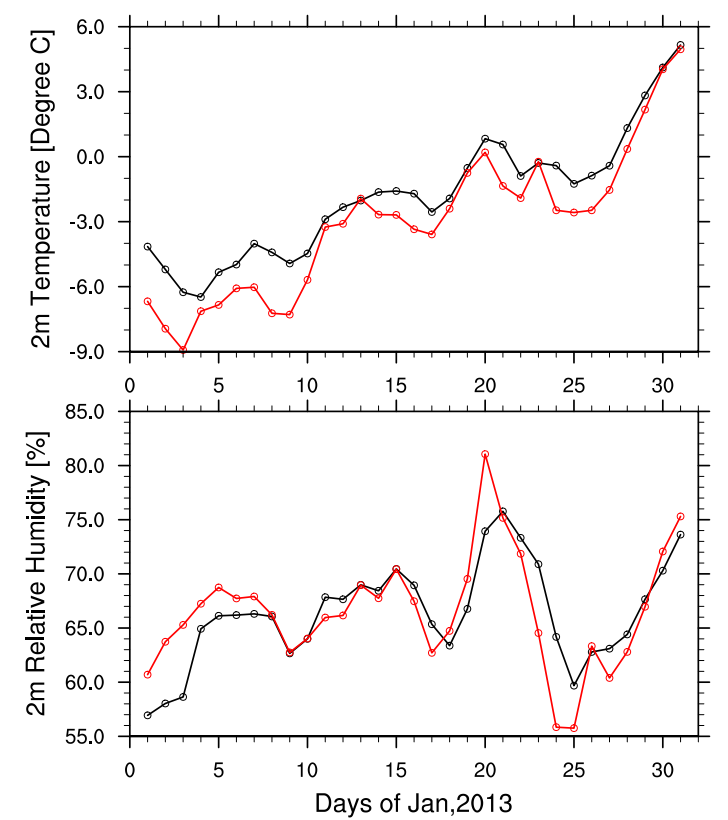

Figure 2. Time series of observed (black line) and simulated (red line) daily meteorological variables averaged over 523 meteorology stations in January 2013.

\subsection{Observations}

The simulation results are compared with meteorological and chemical observations. Daily meteorological observations at 523 stations are obtained from the National Climate Data Center (NCDC) of China Meteorological Administration (CMA), including $2 \mathrm{~m}$ temperature, $2 \mathrm{~m}$ relative humidity (RH), and $10 \mathrm{~m}$ wind speed. The radiosonde profiles at 20 stations are provided by the department of atmospheric science at the University of Wyoming (http://weather.uwyo. edu/upperair/sounding.html).

The measurements of near-surface $\mathrm{PM}_{2.5}$ mass concentrations are obtained from the China National Environmental Monitoring Center (CNEMC). The observation data have been released since January 2013, including hourly concentrations of $\mathrm{SO}_{2}, \mathrm{NO}_{2}, \mathrm{CO}$, ozone $\left(\mathrm{O}_{3}\right), \mathrm{PM}_{10}$ and $\mathrm{PM}_{2.5}$ at 74 big cities in China with 71 of those cities covered by the study domain. Each city has several observation stations, containing both urban and rural stations. In this study, the $\mathrm{PM}_{2.5}$ concentration for one city is the average of all the stations in the city, representing thus a more regional condition of the pollution level. This database allows for a spatially extensive evaluation of air quality simulations by atmospheric models.

\section{Model evaluations}

Accurate representation of meteorology and aerosol concentrations in the model provides the foundations of quantifying
Table 2. Statistical Performance of baseline simulations for meteorology.

\begin{tabular}{lrrrr}
\hline & $\begin{array}{r}\mathrm{T} 2 \\
\left({ }^{\circ} \mathrm{C}\right)\end{array}$ & $\begin{array}{r}\mathrm{RH} 2 \\
(\%)\end{array}$ & $\begin{array}{r}\mathrm{WS} 10 \\
\left(\mathrm{~m} \mathrm{~s}^{-1}\right)\end{array}$ & $\begin{array}{r}\mathrm{PM}_{2.5} \\
\left(\mu \mathrm{g} \mathrm{m}^{-3}\right)\end{array}$ \\
\hline No. of stations & 523 & 523 & 523 & 71 \\
MEAN OBS & -1.8 & 66 & 1.9 & 129.2 \\
MEAN SIM & -2.8 & 66 & 3.9 & 111.5 \\
Corr. $R$ & 0.96 & 0.47 & 0.47 & 0.67 \\
MB & -1.0 & 0 & 2.0 & -18.9 \\
NMB & $-0.4 \% *$ & $<0.1 \%$ & $105 \%$ & $-15.0 \%$ \\
RMSE & 3.4 & 16 & 2.7 & 30.7 \\
\hline
\end{tabular}

* calculated in $\mathrm{K}$

aerosol feedbacks. Therefore, in this section, the model performance is evaluated by comparing model results with surface and radiosonde observations. If not otherwise specified, the model results presented in this section are from the BASE scenario, which represents the most comprehensive realization of different processes in the model. It should be noted that systematic differences may result from the comparison between grid-mean values and point measurements, since a model grid covers an area of $729 \mathrm{~km}^{2}(27 \mathrm{~km} \times 27 \mathrm{~km})$.

\subsection{Meteorology}

Meteorology strongly affects formation, transport, and elimination of atmospheric aerosols. The selected meteorological variables for model evaluation are temperature, relative humidity, and wind speed. Figure 2 shows the time series of observed and simulated daily mean $2 \mathrm{~m}$ temperature and $2 \mathrm{~m}$ relative humidity, with the statistical summary of the comparisons shown in Table 2. The model reproduces temporal variations of these two meteorological variables.

The statistical indices used here are mean observation (MEAN OBS), mean simulation (MEAN SIM), correlation coefficient (Corr. $R$ ), mean bias (MB), normalized mean bias (NMB), and root mean square error (RMSE). The definitions of these indices are given in the Appendix. The model reproduces $2 \mathrm{~m}$ temperature with a correlation of 0.97 and a cold bias of $-1.0^{\circ} \mathrm{C}$, mainly due to underestimation in the first 9 days of the month. Relative humidity is simulated with a correlation of 0.47 and a negligible mean bias. The $10 \mathrm{~m}$ wind speed is systematically overestimated by the model by $105 \%$. A high positive bias in wind speed is also reported by several other studies using WRF-Chem (Matsui et al., 2009; Molders et al., 2012; Tuccella et al., 2012; Zhang et al., 2010). This high-bias probably results from unresolved topographical features in surface drag parameterization and the coarse resolution of the domain (Cheng and Steenburgh, 2005; Yahya et al., 2014).

Air pollution is influenced not only by surface meteorology, but also by vertical patterns of meteorological variables. In Fig. 3, the monthly mean vertical profiles of simulated 

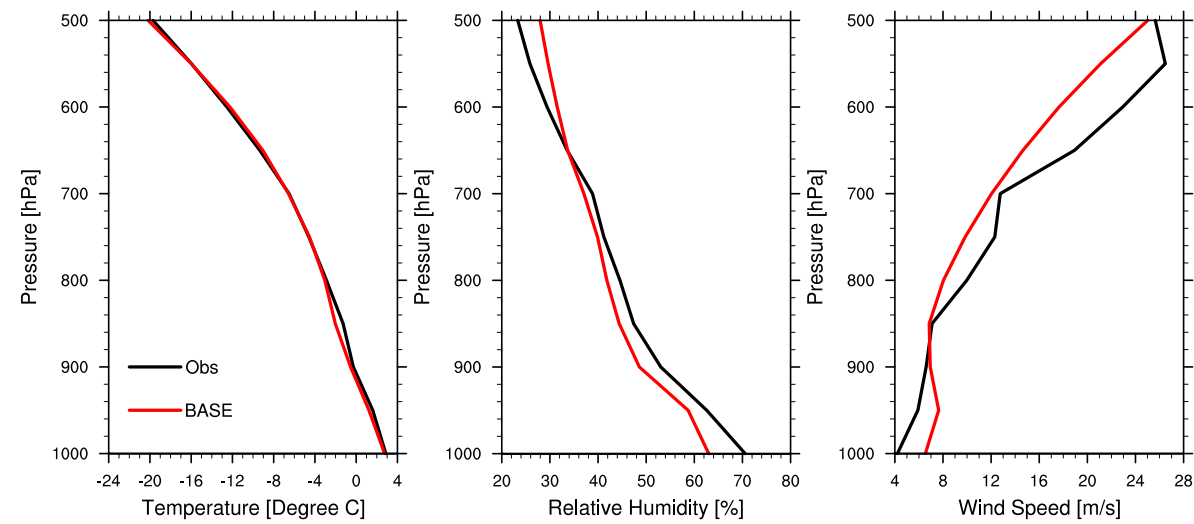

Figure 3. Monthly mean vertical profiles of observed (black line) and simulated (red line) meteorological variables averaged over 36 meteorology stations.

meteorological variables are compared with sounding observations (averaged at 00:00 and 12:00 UTC - universal time coordinated). Generally, the model captures vertical variations of meteorological variables. The model reproduces well the vertical variations of temperature with a small bias. The model underestimates relative humidity below $650 \mathrm{hPa}$ and overestimates it in the upper levels. Wind speeds are overestimated in the lower atmosphere and underestimated in the upper atmosphere. The errors in meteorology may influence the accuracy of simulating processes of aerosol formation, transport and deposition. Overall, the evaluations presented here suggest that the model adequately simulates the spatial and temporal variations of meteorological variables of significant relevance to air quality.

\section{2 $\quad \mathbf{P M}_{2.5}$}

We first evaluated the spatial distribution of simulated monthly mean $\mathrm{PM}_{2.5}$ mass concentrations by comparing model results with observations at 71 big cities in the model domain in January 2013. As shown in Fig. 4, the model captures the spatial patterns of $\mathrm{PM}_{2.5}$ during the month, including high levels of $\mathrm{PM}_{2.5}$ over southern Hebei, Henan, Hubei Province, Sichuan Basin and three big cities (Harbin, Changchun, Shenyang) in northeastern China. The North China Plain (NCP), central China (CC) area, and Sichuan Basin have the highest monthly mean $\mathrm{PM}_{2.5}$ mass concentrations. $\mathrm{PM}_{2.5}$ pollution is more severe over the Yangtze River delta (YRD) than that over the Pearl River delta (PRD).

Figure 5 presents the scatter plots of observed and simulated monthly mean $\mathrm{PM}_{2.5}$ mass concentrations at 71 cities. The model has a low bias ranging from 25 to $70 \%$ for cities with monthly mean $\mathrm{PM}_{2.5}$ exceeding $200 \mu \mathrm{g} \mathrm{m}^{-3}$. The observed and simulated time series of hourly surface $\mathrm{PM}_{2.5}$ averaged over all the cities are compared in Fig. 6. The model simulates hourly $\mathrm{PM}_{2.5}$ with a temporal correlation of 0.67 , and underestimates monthly mean $\mathrm{PM}_{2.5}$ mass concentra-

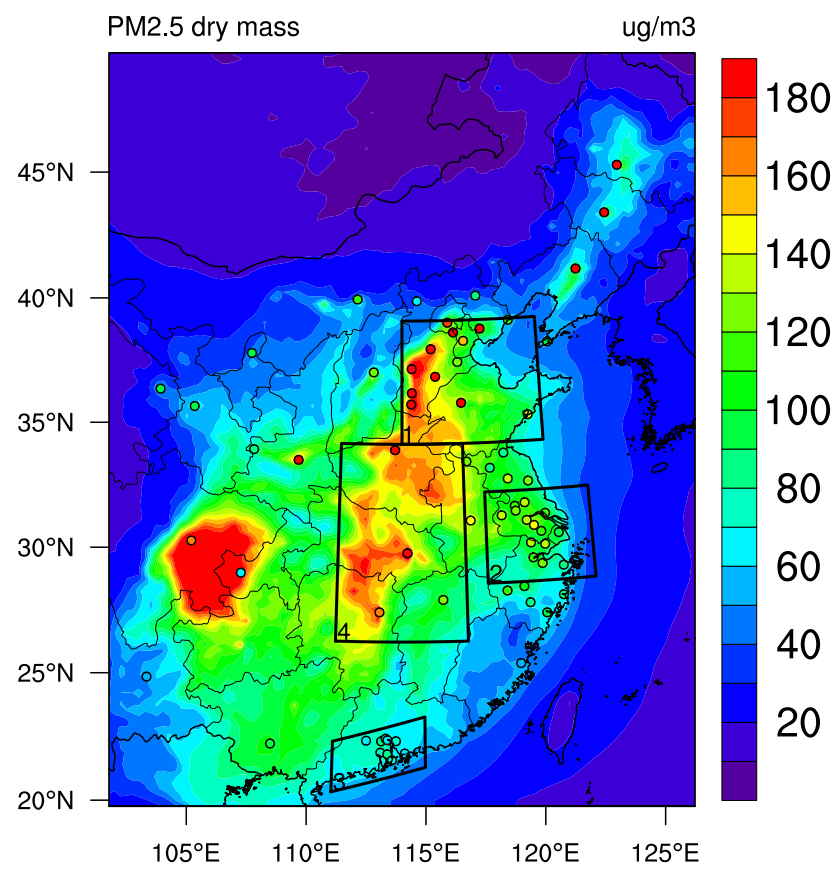

Figure 4. Simulated and observed (circles) monthly mean $\mathrm{PM}_{2.5}$ mass concentration over eastern China in January 2013. The four polygons correspond to the North China Plain (NCP) (1), the Yangtze River delta (YRD) (2), the Pearl River delta (PRD) (3), and central China (4).

tions by $18.9 \mu^{-3} \mathrm{~m}^{-3}(15.0 \%)$. The model generally reproduces the observed temporal variations of $\mathrm{PM}_{2.5}$.

The enhancement ratio is employed to further evaluate the model performance in simulating $\mathrm{PM}_{2.5}$ temporal variations in different regions. Within a given grid point, the enhancement ratio is defined as the average of daily $\mathrm{PM}_{2.5}$ mass concentrations exceeding the median divided by that less than the median, representing changes of $\mathrm{PM}_{2.5}$ from clean to polluted situations. As shown in Table 3, observed enhancement ratios are around 1.6 over the NCP, YRD, PRD and CC. The 

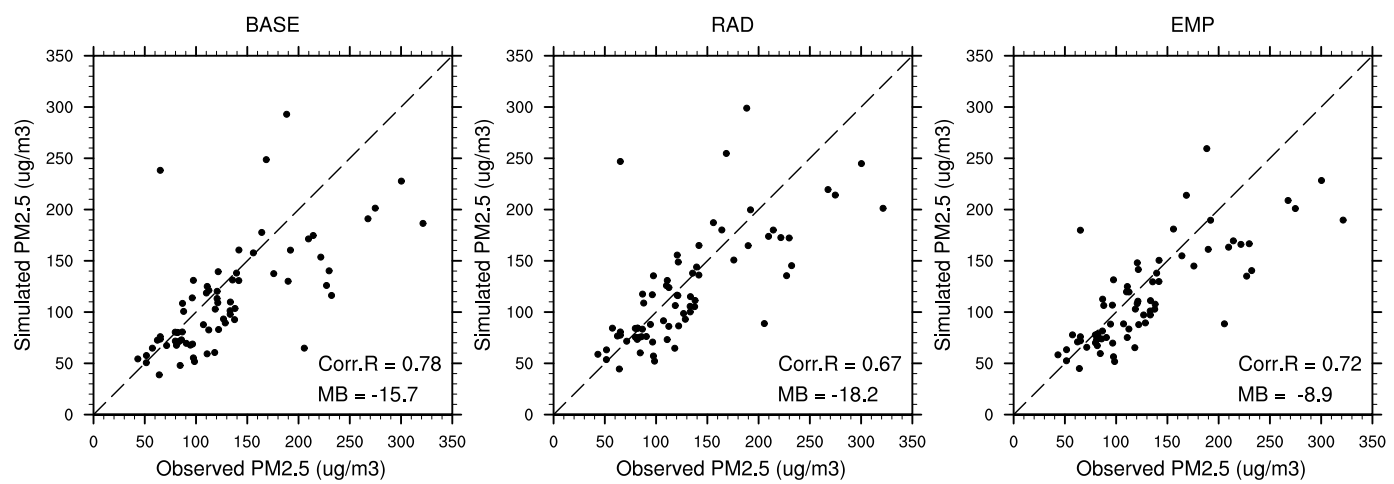

Figure 5. Scatter plots of monthly mean $\mathrm{PM}_{2.5}$ mass concentrations in 71 cities in January 2013.

\section{Temporal Variations of PM2.5}

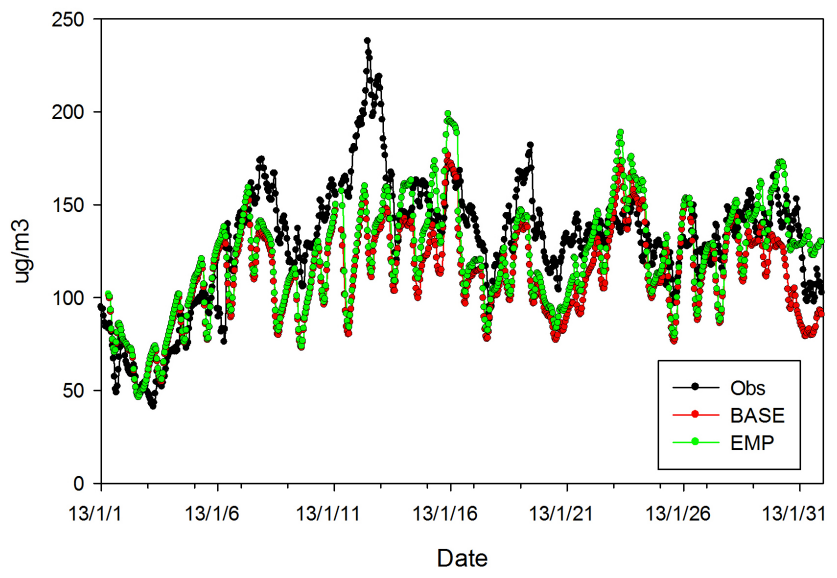

Figure 6. Comparison of observed (black) and simulated (red for the BASE scenario and blue for the EMP scenario) hourly nearsurface $\mathrm{PM}_{2.5}$ mass concentrations averaged over 71 cities in China in January 2013.

simulated enhancement ratios range from 1.8 to 2.0 over the four regions, which are close to observations. Since changes of hourly emissions are not considered in this study, $\mathrm{PM}_{2.5}$ enhancements mainly result from worsened meteorological conditions and more production of secondary aerosols. The consistency of the simulated enhancement ratios with the observed ones by region indicates that the WRF-Chem model has some success in simulating the changes of meteorological and chemical processes from clean to polluted situations.

However, the model fails to capture the extremely high values of $\mathrm{PM}_{2.5}$ during the haze episodes in January 2013, e.g., 13-15 and 18-20 January. Both positive and negative biases exist in simulated hourly $\mathrm{PM}_{2.5}$. The model's underestimation during the severe winter haze episodes is consistent with previous studies (Liu et al., 2010; L. T. Wang et al., 2014; Y. X. Wang et al., 2014; Zhou et al., 2014). Possible reasons for this underestimation are (1) the bias in simulating meteorological conditions during haze episodes; (2) un-
Table 3. Observed and simulated enhancement ratios of $\mathrm{PM}_{2.5}$. The enhancement ratio is defined as the average of daily $\mathrm{PM}_{2.5}$ larger than the median value divided by that of hourly $\mathrm{PM}_{2.5}$ less than the median value during the month. NCP, YRD, PRD, and CC as defined in the text.

\begin{tabular}{lrrrr}
\hline & NCP & YRD & PRD & CC \\
\hline Observations & 1.7 & 1.6 & 1.5 & 1.7 \\
WRF-Chem (BASE) & 1.6 & 1.7 & 1.6 & 1.7 \\
\hline
\end{tabular}

certainties in emissions; (3) missing SOA in the MOSAIC mechanism, which will be addressed below; and (4) the lack of formation mechanisms of secondary inorganic aerosols, like heterogeneous oxidation of $\mathrm{SO}_{2}$ on the surface of particulate matter (Harris et al., 2013). By adjusting $\mathrm{SO}_{2}$ and $\mathrm{NO}_{\mathrm{x}}$ emissions according to surface observations and parameterizing the heterogeneous oxidation of $\mathrm{SO}_{2}$ on deliquesced aerosols in the GEOS-Chem model, Y. X. Wang et al. (2014) reported improvements of simulated $\mathrm{PM}_{2.5}$ spatial distribution and an increase of $120 \%$ in sulfate fraction in $\mathrm{PM}_{2.5}$. The traditional offline models do not include the aerosol feedbacks on meteorology, which may cause a low bias of $\mathrm{PM}_{2.5}$ for the severe pollution episodes. The inclusion of aerosol feedbacks in atmospheric models improves the model performance, which will be discussed in Sect. 5 .

\subsection{SOA}

The MOSAIC aerosol module used in the three scenarios does not include SOA. Here we examine the sensitivity of modeled $\mathrm{PM}_{2.5}$ to SOA by replacing MOSAIC with the MADE/SORGAM aerosol module in the BASE scenario. The test period is 6-10 January 2013. The mean SOA simulated from MADE/SORGAM is $0.3 \mu \mathrm{g} \mathrm{m}^{-3}$, making up only $2.8 \%$ of OA (organic aerosol; Table 4). This is comparable with the magnitude of simulated winter SOA concentrations reported by another study using WRF-Chem for the whole China (Jiang et al., 2012). The low SOA concentrations simulated by the model can be explained by low emis- 
Table 4. Modeled SOA, OA and $\mathrm{PM}_{2.5}$ using MADE/SORGAM and MOSAIC in comparison with observations. The data shown are spatially averaged over 71 big cities and temporally averaged during 6-10 January 2013.

\begin{tabular}{lrrrrr}
\hline & $\begin{array}{r}\mathrm{SOA} \\
\left(\mu \mathrm{g} \mathrm{m}^{-3}\right)\end{array}$ & $\begin{array}{r}\mathrm{OA} \\
\left(\mu \mathrm{g} \mathrm{m}^{-3}\right)\end{array}$ & SOA/OA & $\begin{array}{r}\mathrm{PM}_{2.5} \\
\left(\mu \mathrm{g} \mathrm{m}^{-3}\right)\end{array}$ & $\begin{array}{r}\mathrm{NMB} \mathrm{of}_{2.5} \\
\mathrm{PM}_{2.5}\end{array}$ \\
\hline MADE/ & & & & & \\
SORGAM & 0.3 & 9.4 & $2.8 \%$ & 68.3 & $49.7 \%$ \\
MOSAIC & & & & 115.4 & $15.0 \%$ \\
Observations & & & & 135.7 & \\
\hline
\end{tabular}

sions of biogenic VOCs (key precursors of SOA) and low temperatures in wintertime. Recent observations have suggested much higher SOA concentrations at Chinese cities in winter, pointing to the importance of anthropogenic VOCs as SOA precursors in China (R. J. Huang et al., 2014); however, a thorough investigation of this issue is outside the scope of this study. As shown in Table 4, the NMB of $\mathrm{PM}_{2.5}$ with the MADE/SORGAM option is more than 3 times larger than that with MOSAIC. Since the modeled SOA has a small contribution to total $\mathrm{PM}_{2.5}$, the MOSAIC aerosol module is chosen in this study and the omission of SOA in MOSAIC is not expected to affect our analysis of the aerosol effects on meteorology.

\section{Aerosol feedbacks on meteorology and air quality}

As seen in the previous section, the WRF-Chem model has shown some success in simulating meteorology and $\mathrm{PM}_{2.5}$. Therefore, in this section, we aim to characterize and quantify the aerosol feedbacks on meteorology and air quality by comparing the three different scenarios described in Sect. 2.

In addition to different setups of the aerosol-radiationcloud feedbacks, differences among the three scenarios can also result from model noise, such as errors in numerical computation and disturbances from discrete updating of initial and boundary conditions. The Student $t$ test is employed to identify statistically significant differences between the scenarios. The null hypothesis is that the two scenarios in comparison give the same simulation results. The sample size is 744 ( $24 \mathrm{~h} \times 31$ days) for each meteorological and chemical variable in a given grid box. Rejection of the null hypothesis indicates that the difference between the two scenarios is significantly different. The Appendix describes the calculation of the $t$ statistic in more detail. We only present and discuss aerosol-induced changes of meteorological and chemical variables which exceed a $95 \%$ confidence interval.

\subsection{Feedbacks on meteorology}

The evolution of atmospheric aerosols is strongly influenced by meteorological variables such as solar radiation, air temperature, and wind speed. Figure 7 illustrates the mean im-

\section{Total Effects}

\section{Radiative Effects}
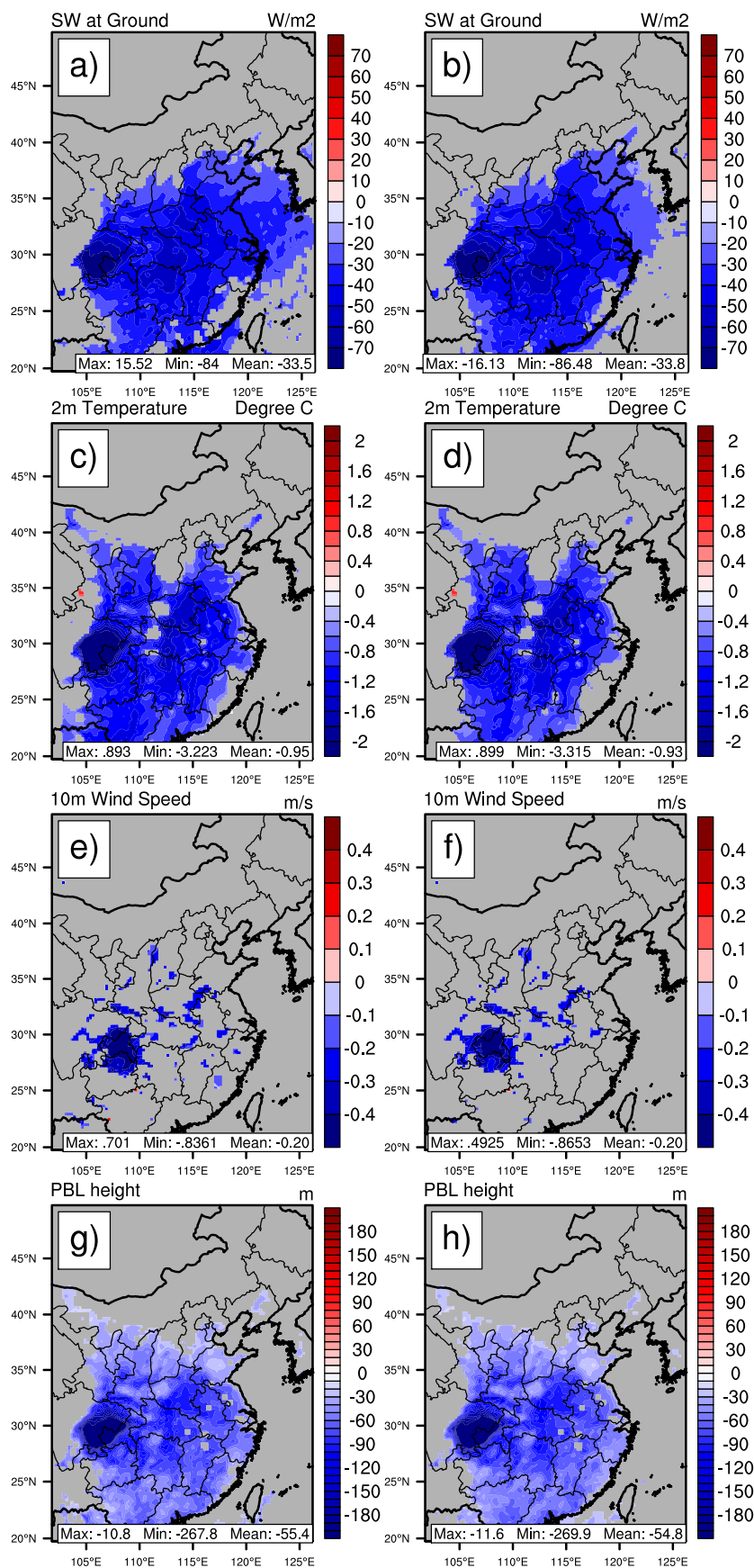

Figure 7. Simulated aerosol total effects (BASE - EMP) and radiative effects (RAD - EMP) on downward shortwave flux at ground, $2 \mathrm{~m}$ temperature, $10 \mathrm{~m}$ wind speed and PBL height in January 2013. The aerosol indirect effects on these four meteorological variables are not shown here since the induced changes are not significant according to Student's $t$ test. Grey shaded areas indicate regions with less than $95 \%$ significance. 
pact of aerosols on downward shortwave flux at the ground, $2 \mathrm{~m}$ temperature, $10 \mathrm{~m}$ wind speed and PBL height over eastern China in January 2013. Downward shortwave flux at the ground is strongly influenced by the existence of atmospheric aerosols, especially over high aerosol-loading regions. Aerosols affect shortwave radiation reaching the ground in two ways. First, particles scatter and absorb incoming solar radiation directly, resulting in surface dimming. Second, in-cloud particles change cloud lifetime and albedo, thus, causing variations of shortwave radiation at the ground surface. As in Fig. 7a, the downward shortwave flux at the ground is reduced over the vast areas of eastern China by up to $-84.0 \mathrm{~W} \mathrm{~m}^{-2}$, which mainly results from the aerosol radiative effects (Fig. 7b). Consistent with our findings, Bi et al. (2014) and Che et al. (2014) report strong negative aerosol direct radiative forcing at the surface (with maximum daily mean exceeding $-200.0 \mathrm{~W} \mathrm{~m}^{-2}$ ) through analysis of groundbased measurements, aerosol optical and radiative properties over the NCP in January 2013.

When the downward shortwave flux at the ground is decreased due to aerosol interception, near-surface energy fluxes are suppressed, leading to weaker convection. Nearsurface air is heated mainly by longwave radiation emitted from the ground. In the case of decreasing shortwave flux at the ground, the near-surface air is cooled and less longwave radiation is emitted from the surface. Due to weaker convection resulting from less shortwave radiation reaching the ground, $2 \mathrm{~m}$ temperature is reduced by up to $3.2^{\circ} \mathrm{C}, 10 \mathrm{~m}$ wind speed is reduced by up to $0.8 \mathrm{~m} \mathrm{~s}^{-1}$, and PBL height is also reduced by up to $268 \mathrm{~m}$, as shown in Fig. 7c, e and $\mathrm{g}$, respectively. Meteorological variables such as air temperature, wind speed, and PBL height could also be influenced by other factors like land surface properties (Zhang et al., 2010), in addition to solar radiations. The change of these variables, especially wind speed, is less significant than that of solar radiation. First, solar radiation is reduced by $21 \%$ over the regions with significant changes, while wind speed and PBL height are reduced by 6 and $14 \%$, respectively. Second, as shown in Fig. 7, the regions with significantly reduced solar radiation are much larger than those with significantly reduced wind speed or PBL height. However, the spatial pattern of the changes of these variables is consistent with that of downward shortwave flux, which indicates that a more stable lower atmosphere resulting from less shortwave radiation plays an important role in aerosol feedbacks. The aerosol indirect effects during the severe haze episodes are found to be not significant in altering solar radiation, temperature, wind speed or PBL height over eastern China, which is not shown here. Overall, the near-surface atmosphere is more stable when aerosol feedback is considered in the model, which enhances pollution accumulation.

The amount of precipitation is low in January 2013 for most regions in China (Wang and Zhou, 2005). Cloud and precipitation formation mainly occurs over areas in the south and over the ocean (Fig. 8a, d). In this month, the changes of cloud and precipitation due to aerosol radiative effects are not significant (Fig. 8h). Aerosol indirect effects directly alter cloud properties such as effective radius, cloud lifetime, and precipitation rate. As shown in Fig. 8i, aerosol indirect effects play a much more significant role in changing cloud properties, mostly in the south. Cloud water path is greatly reduced by up to $5.7 \mathrm{~kg} \mathrm{~m}^{-2}$ over the junction of Yunnan and the Guizhou Province and the ocean around Taiwan. The reduction over these relatively clean areas may be explained by the smaller droplet number mixing ratio which is derived from lower particle number concentrations in the BASE scenario. The scenarios without aerosol indirect effects adopt the default value droplet number mixing ratio of $1.0 \times 10^{8}$ particles per $\mathrm{kg}$ of air which does not vary with aerosol number concentrations. The reduced cloud droplet number results in accelerating auto-conversion to rain droplets. Thus, simulated monthly precipitation is increased by almost $100 \%$ over these areas (Fig. 8j). Similar results are found when we replace the Lin microphysics scheme by the two-moment Morrison scheme (Morrison et al., 2009). Previous model assessments also showed that the inclusion of aerosol indirect effects reduced cloud water content over the South Pacific Ocean and improved model comparison with aircraft observations (Yang et al., 2011). The relatively small precipitation, as well as small changes of precipitation due to aerosol feedbacks over the north of the domain, suggests that precipitation has a minor effect on near-surface aerosols in January 2013.

Several studies under the Air Quality Model Evaluation International Initiative (AQMEII) project suggested that the aerosol indirect effect dominated in aerosol feedbacks on solar radiation, temperature, and PBL height (Forkel et al., 2012, 2014; Kong et al., 2014; Makar et al., 2014a). Different from these studies, we find that aerosol indirect effects have little influence on the downward shortwave flux at the ground, $2 \mathrm{~m}$ temperature, $10 \mathrm{~m}$ wind speed, and PBL height (not shown here). In order to investigate how grid resolution relates to the aerosol indirect effect, we have conducted another three groups of nested grid runs, using the same scenarios (BASE, RAD, and EMP). The outer domain is the same as the previous domain, but a $9 \mathrm{~km}$ nested domain covering the North China Plain is added. In the nested domain, cumulus parameterization is turned off. We find that with the finerresolution simulation, the aerosol direct effect still dominates over the NCP and the aerosol indirect effect is not significant, suggesting grid resolution might not be the reason why the aerosol indirect effect is minor in our study.

The discrepancy relating to the aerosol indirect effect between those studies under AQMEII and our work may be explained by three reasons. First, we focus on a low-cloudcover winter case, especially in northern China. It is confirmed by both the more sophisticated Morrison scheme and the finer-resolution $(9 \mathrm{~km})$ nested grid simulation that cloud cover is low in northern China. Studies under AQMEII focused on summertime, when aerosol indirect effects on so- 

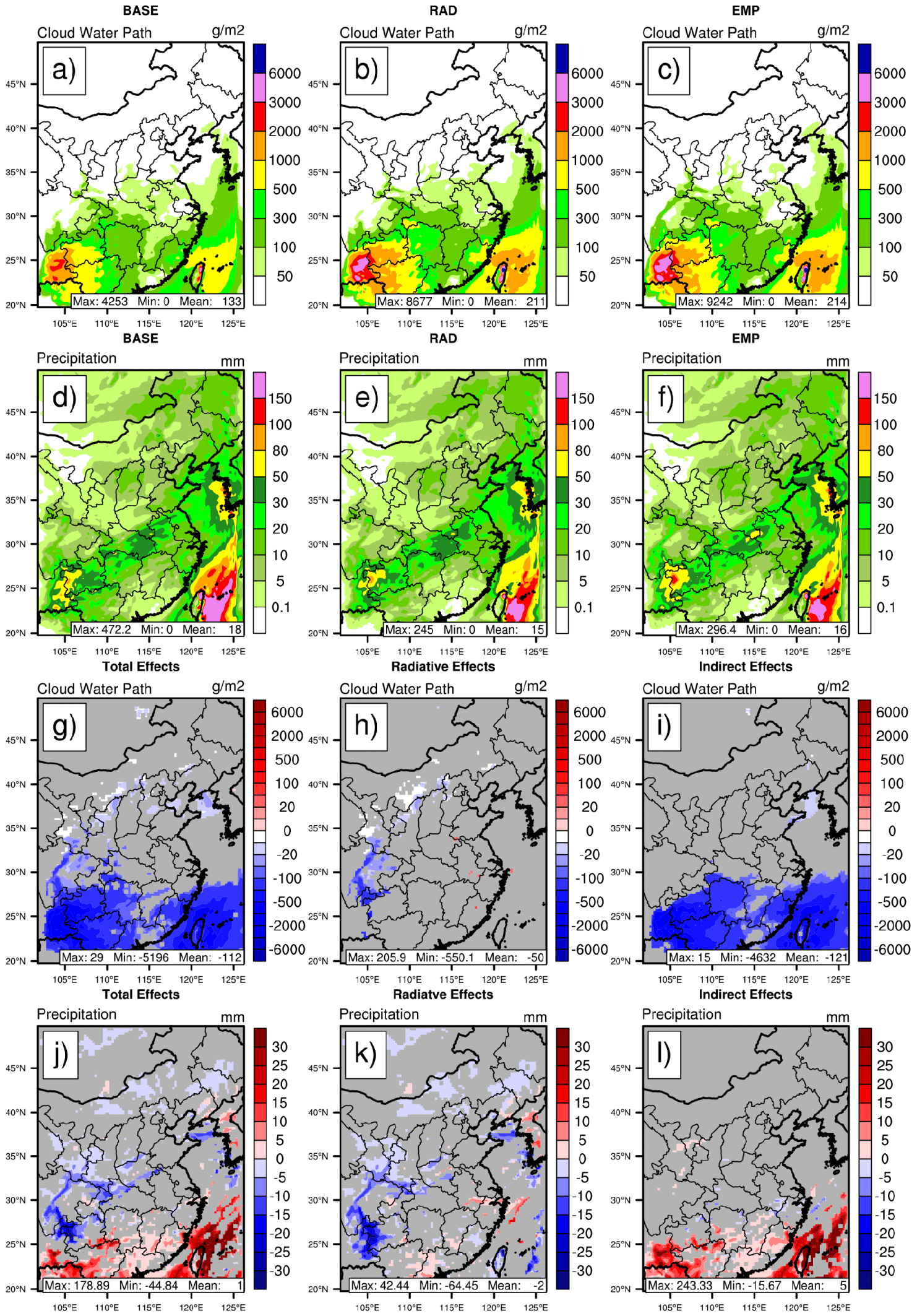

Figure 8. Simulated cloud water path (a-c) and precipitation (d-f) for the three scenarios and aerosol total effects (BASE - EMP) (g, j), radiative effects (RAD - EMP) (h, k), and indirect effects (BASE - RAD) (i, l) over eastern China in January 2013. Grey shaded areas indicate regions with less than $95 \%$ significance. 


\section{BASE}
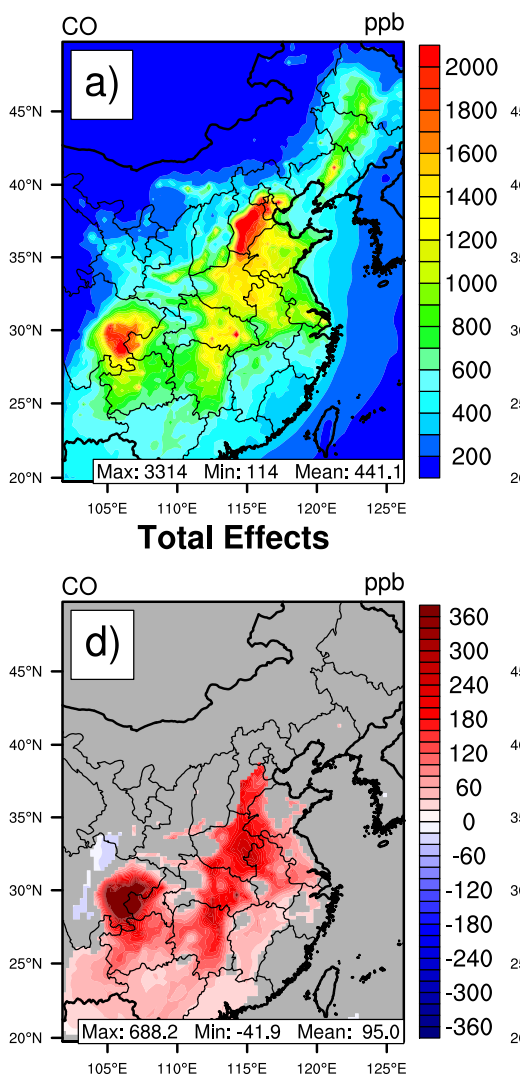

BASE

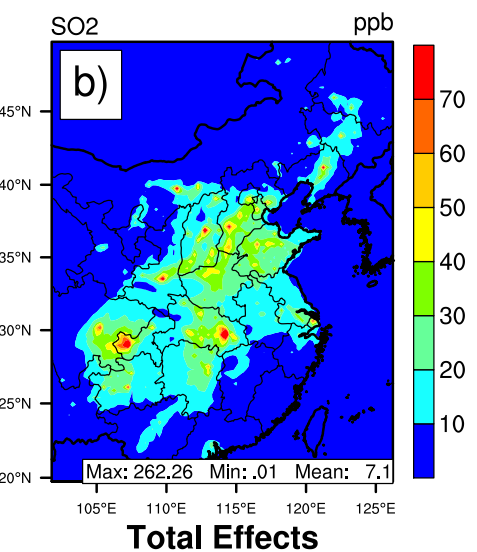

Total Effects

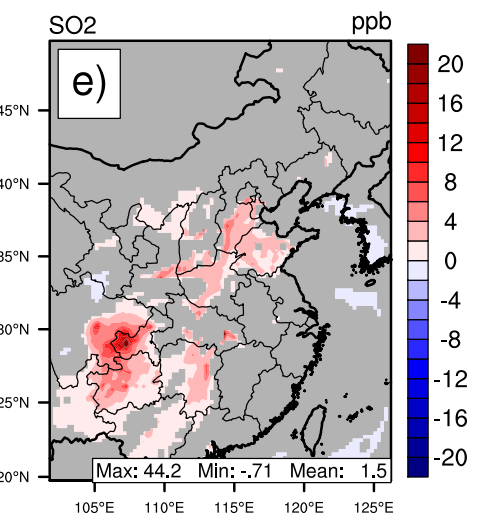

BASE
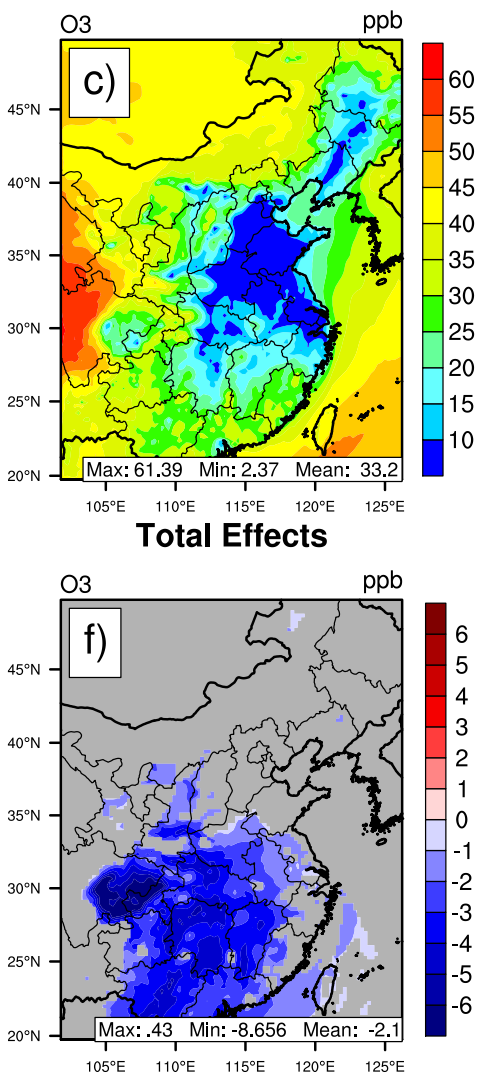

Figure 9. Simulated monthly mean $\mathrm{CO}, \mathrm{SO}_{2}$, and $\mathrm{O}_{3}$ mixing ratios and aerosol feedbacks (BASE - EMP) on the three gas pollutants over eastern China in January 2013. Grey shaded areas indicate regions with less than $95 \%$ significance.

lar radiation, temperature, and PBL height were found to be most pronounced (Forkel et al., 2014). Second, under high aerosol loading conditions (for example, fire conditions in Kong et al. (2014) and haze conditions in our study), the aerosol direct effect is found to dominate over the aerosol indirect effect. The aerosol indirect effect was found to dominate over clean ocean and near the ocean's coast (Forkel et al., 2014; Kong et al., 2014). Third, we do find some regions dominated by the aerosol indirect effect. However, the Student $t$ test filters the values over those regions because the changes due to the aerosol indirect effect are not statistically significant.

Ice crystals can be formed by activation of ice nuclei (IN). Recently, increasing evidence has suggested that aerosols, especially dust, black carbon, and organic matter, can influence cloud physical process by acting as IN (Tao et al., 2012). The WRF-Chem version in this work does not include direct interactions of aerosol number concentration with ice nuclei, which may be another reason for the possible underestimation of aerosol indirect effects.

\subsection{Feedbacks on air quality}

Through moderating meteorological variables, aerosols exert feedbacks on air quality. Figure 9 shows spatial distributions of $\mathrm{CO}, \mathrm{SO}_{2}$, and $\mathrm{O}_{3}$ and the feedbacks of aerosols on these three gas pollutants in January 2013. Spatial patterns of $\mathrm{CO}$ and $\mathrm{SO}_{2}$ are similar to that of $\mathrm{PM}_{2.5}$. The near-surface $\mathrm{CO}$ and $\mathrm{SO}_{2}$ concentrations are increased when aerosol feedbacks are included. Over the domain, $\mathrm{CO}$ is enhanced by up to $446 \mathrm{ppb}$, while $\mathrm{SO}_{2}$ is increased by as much as $28 \mathrm{ppb}$. Large increases of $\mathrm{CO}$ and $\mathrm{SO}_{2}$ are found over areas with high aerosol loading. This phenomenon may mainly result from a lower PBL and a more stable atmosphere near the surface due to aerosol radiative effects, as discussed in Sect. 3.2. We also found aerosol indirect effects do not have significant influence on gas pollutants.

The formation of $\mathrm{O}_{3}$ is directly related to solar radiation and temperature in regions with sufficient $\mathrm{NO}_{\mathrm{x}}$ and VOCs. The lower air temperature and reduced incoming solar radiation as a result of aerosol radiative effects lead to a reduced photolysis rate of $\mathrm{NO}_{2}$ and consequently reduce $\mathrm{O}_{3}$ concentrations. The largest suppression of surface ozone by aerosols is found to be up to $-6.9 \mathrm{ppb}$ in the warmer southern China. 
Changes in northern China are relatively small. These findings are similar to those in Zhang et al. (2010), Forkel et al. (2012), Kong et al. (2014) and Makar et al. (2014b).

The aerosol-radiation-cloud feedbacks on near-surface aerosol mass concentrations are illustrated in Fig. 10. As shown in Fig. 10a, both increases and decreases of $\mathrm{PM}_{2.5}$ are found in the domain. Enhanced $\mathrm{PM}_{2.5}$ mass concentrations are simulated over Henan, Hubei, Guangxi Province, and the Sichuan Basin with the maximum enhancement of $69.3 \mu \mathrm{g} \mathrm{m}^{-3}$. Reductions in $\mathrm{PM}_{2.5}$ by as much as $-38.2 \mu \mathrm{g} \mathrm{m}^{-3}$ are simulated over the Bohai Sea's surrounding area, northeastern China and the conjunction area of Yunnan, Guangxi, and the Guizhou Province (southwestern China).

In order to better understand the mechanisms of how $\mathrm{PM}_{2.5}$ responds to aerosol feedbacks, the aerosol effects are divided into aerosol radiative effects (Fig. 10b) and indirect effects (Fig. 10c). $\mathrm{PM}_{2.5}$ can be influenced by the changes in various atmospheric processes due to aerosol radiative effects. For example, lower temperature may suppress the formation of sulfate, and reduced solar radiation may inhibit the oxidation of precursors of secondary aerosols. Among the various changes in atmospheric processes, the reduced PBL height and the stabilized lower atmosphere may be the most important factors to explain the increase of $\mathrm{PM}_{2.5}$ caused by the aerosol radiative effects, since primary gas pollutants also increase when aerosol radiative effects are included. In Fig. $11 \mathrm{~b}$, we can see that $\mathrm{PM}_{2.5}$ is greatly increased by aerosol radiative effects over the region where solar radiation and PBL height are significantly reduced during winter haze (Fig. 7a, g). The mechanism involved is that aerosol radiative effects stabilize the lower atmosphere and suppress the dilution and ventilation of $\mathrm{PM}_{2.5}$ as well as primary gas pollutants.

The comparison between Fig. 10a and $\mathrm{c}$ indicates that aerosol indirect effects are the main reason of the suppression of $\mathrm{PM}_{2.5}$. The reduction of $\mathrm{PM}_{2.5}$ in WRF-Chem simulations with aerosol indirect effects mainly comes from three aspects. First, once aerosol indirect effects are included in the model, the cloud droplet number is based on a simulated atmospheric aerosol number different than what is prescribed in the model. This coding strategy allows interstitial air-borne aerosols to become cloud-borne aerosols after activation. Therefore, air-borne aerosols are reduced in simulations including aerosol indirect effects, especially over cloudy regions like southwestern China (Fig. 8a). Second, enhanced precipitation may also help reduce the air-borne particles, especially in the south. Third, in the simulations including aerosol indirect effects, a more comprehensive inand below-cloud aerosol wet removal module following the method of Easter et al. (2004) is employed, while in the simulations without aerosol indirect effects, this module is not activated. In this aerosol wet removal mechanism, the removal processes are assumed to be irreversible, and aerosol resuspension is not considered even when precipitation is weak.
This leads to a stronger removal of atmospheric aerosols when aerosol indirect effects are included. It should be noted that in this work, the enhancement of aerosol wet removal process, when including aerosol indirect effects in the model, mainly results from WRF-Chem model configurations used here, not from aerosol-induced changes in cloud properties or precipitation.

The above discussion is based on model results temporally averaged during the whole month. In order to better understand $\mathrm{PM}_{2.5}$ variations on a day to day basis, four cities with significant $\mathrm{PM}_{2.5}$ enhancements and four cities with significant $\mathrm{PM}_{2.5}$ reductions are selected. Figure 11 shows the time series of observed and simulated hourly surface $\mathrm{PM}_{2.5}$ mass concentrations in the selected eight cities in January 2013. The four cities with increasing monthly mean $\mathrm{PM}_{2.5}$ due to aerosol feedbacks are Zhengzhou, Wuhan, Changsha, and Chengdu (left panels in Fig. 11). Major enhancements of $\mathrm{PM}_{2.5}$ are simulated when $\mathrm{PM}_{2.5}$ levels are high, for example, during the period of 15-17 January. The changes in $\mathrm{PM}_{2.5}$ have a moderate negative correlation with the changes in PBL height (correlations coefficient $\approx-0.3$ ) at the four cities, suggesting that the $\mathrm{PM}_{2.5}$ enhancement is partly caused by decreased PBL height in these regions. The reduction of $\mathrm{PM}_{2.5}$ in Qinhuangdao, Tianjin, Shenyang, and Changchun (right panels in Fig. 11), which are the four cities with decreased monthly mean $\mathrm{PM}_{2.5}$, mainly happens in the last 5 days of the month (26-31 January).

In summary, aerosol radiative effects reduce the downward shortwave flux at the ground, decrease near-surface temperature and wind speed, and further weaken convection, all leading to a more stable lower atmosphere. In a more stable lower atmosphere due to aerosol radiative effects, primary gas pollutants $\left(\mathrm{CO}\right.$ and $\left.\mathrm{SO}_{2}\right)$ and $\mathrm{PM}_{2.5}$ are enhanced, while $\mathrm{O}_{3}$ is decreased because of less incoming solar radiation and lower temperatures. $\mathrm{PM}_{2.5}$ is reduced when aerosol indirect effects are included, mainly due to the transition from airborne aerosol to cloud-borne aerosol and the activation of a more comprehensive aerosol wet removal module. The underestimations at the higher end indicate that some key mechanisms are missing in the model, especially the production of secondary aerosols.

\section{Effects of including aerosol feedbacks on model performance}

In this section we address the question of whether including aerosol feedbacks within the model improves model performance in simulating severe haze episodes. Model results from the BASE (with all aerosol feedbacks) and EMP (without any aerosol feedbacks) scenarios are compared with observations to evaluate which scenario is more consistent with reality.

As an example to shown the extent to which simulated meteorological variables are affected by including aerosol 

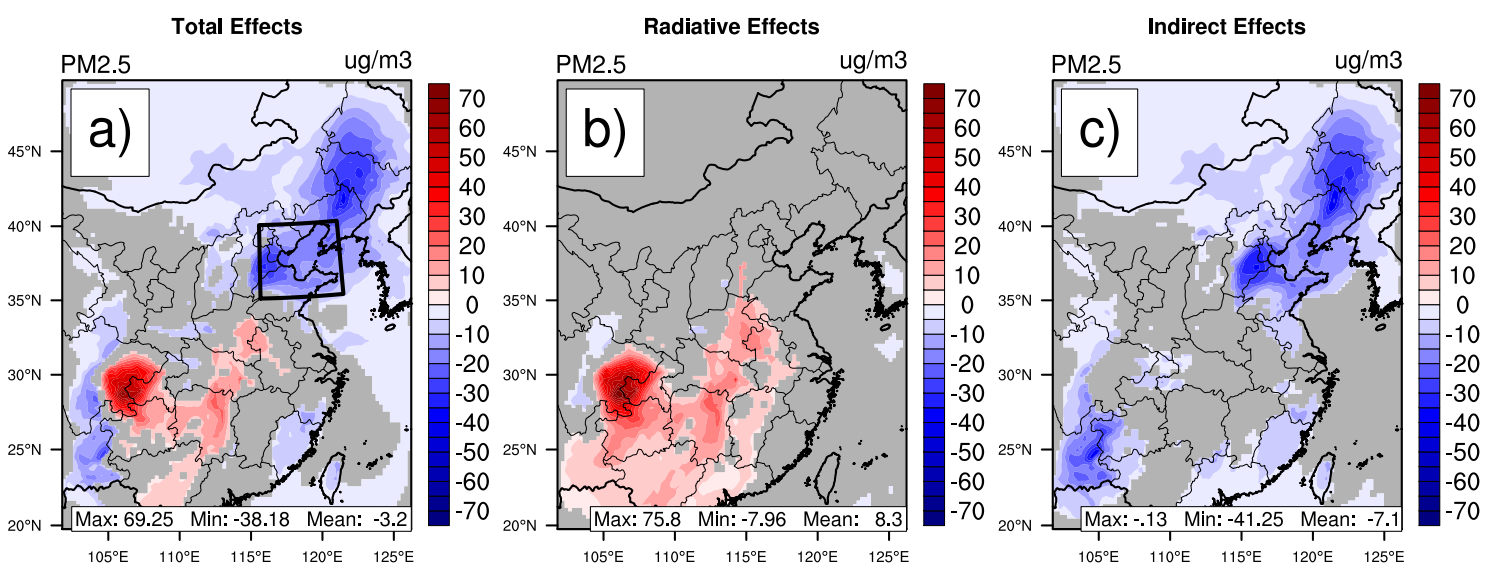

Figure 10. Simulated aerosol total effects (BASE - EMP), radiative effects (RAD - EMP), and indirect effects (BASE - RAD) on monthly mean $\mathrm{PM}_{2.5}$ over eastern China in January 2013. Grey shaded areas indicate regions with less than $95 \%$ significance. The black polygon defines the Bohai Sea's surrounding area.
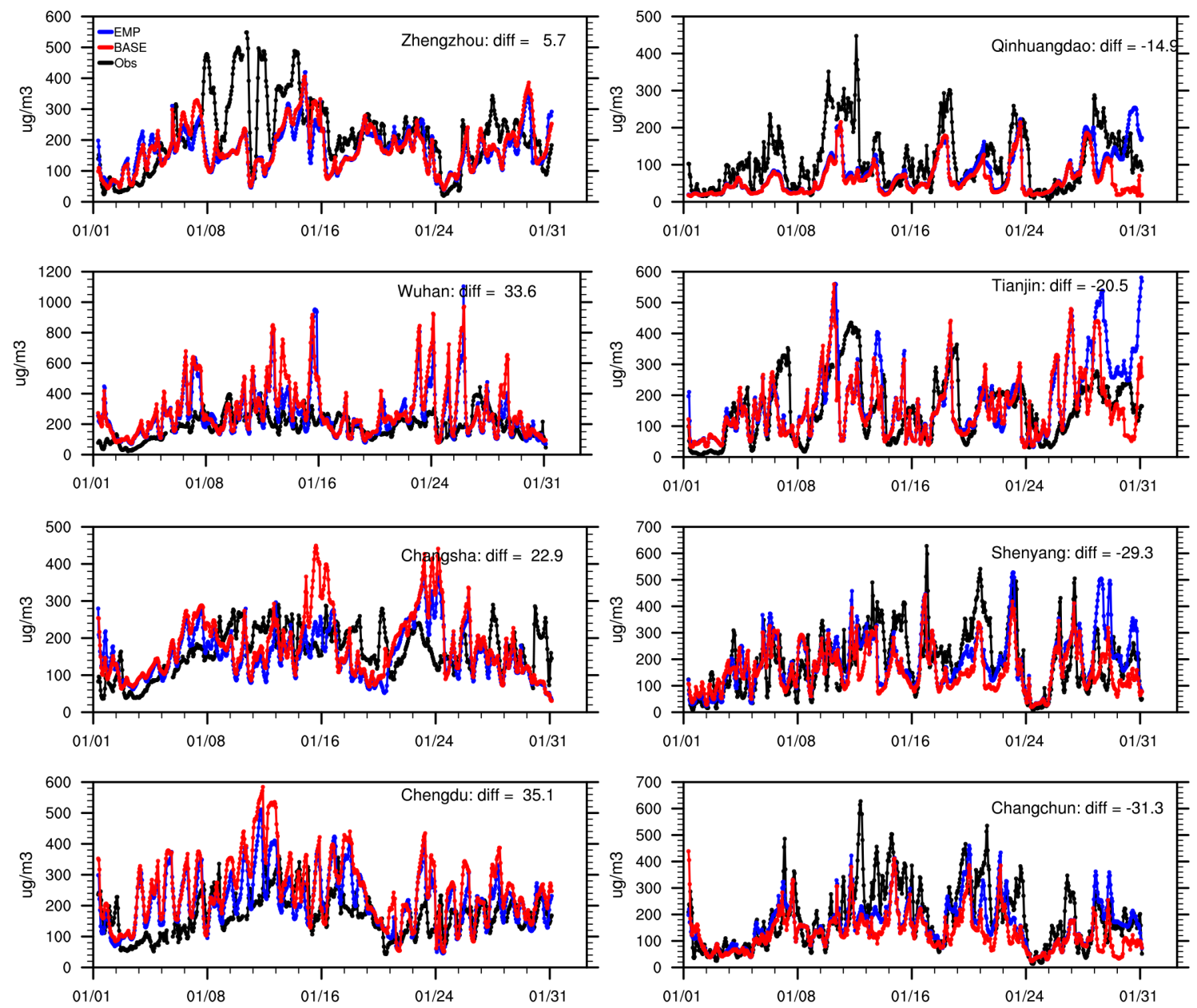

Figure 11. Time series of observed (black) and simulated (red for BASE scenario and blue for EMP scenario) hourly surface PM 2.5 mass concentrations in eight cities for January 2013. Monthly mean $\mathrm{PM}_{2.5}$ is enhanced in the four cities (Zhengzhou, Wuhan, Changsha, and Chengdu) in the left column. Cities in the right column have suppressed monthly mean $\mathrm{PM}_{2.5}$ mass concentrations. "Diff" indicates aerosol feedbacks (BASE - EMP) on monthly mean $\mathrm{PM}_{2.5}$ mass concentrations. 

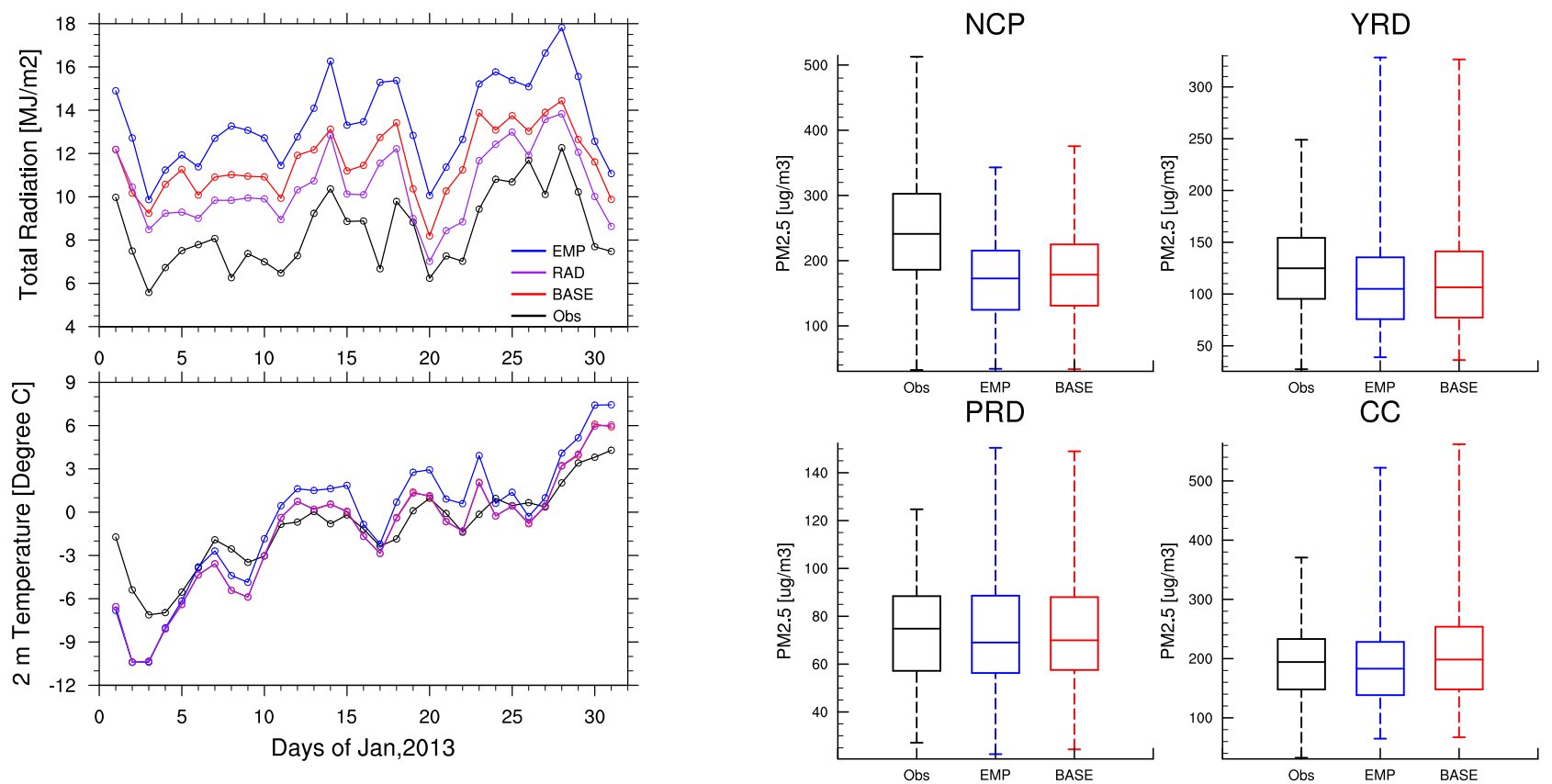

Figure 12. Time series of observed (black) and simulated (red for the BASE scenario, purple for the RAD scenario, and blue for the EMP scenario) daily total radiation and $2 \mathrm{~m}$ temperature averaged over northern and central China in January 2013.

feedbacks, Fig. 12 compares downward shortwave radiation at the ground and $2 \mathrm{~m}$ temperature among the three scenarios over NCP, where $\mathrm{PM}_{2.5}$ pollution is most severe in January 2013. All scenarios have a high bias in daily total shortwave radiation at the ground, mainly due to the overestimation of maximum shortwave radiation at noon (Z. F. Wang et al., 2014). However, the inclusion of all aerosol feedbacks (BASE) leads to a $22 \%$ reduction of the normalized mean bias. Simulated shortwave radiation in the RAD scenario has the smallest bias. The model prediction of $2 \mathrm{~m}$ temperature is also improved in the scenario with aerosol feedbacks during haze episodes, such as on $12-15$ and 1924 January. These findings are consistent with the those from Z. F. Wang et al. (2014), indicating the importance of including aerosol feedbacks in simulating meteorology under high aerosol loading conditions.

Figures 5 and 6 compare simulated $\mathrm{PM}_{2.5}$ over 71 big cities in January 2013 in the BASE and EMP scenarios averaged temporally and spatially, respectively. However, no significant improvements are found when aerosol feedbacks are included, partially due to temporal and spatial averaging. So we further investigate the model performance in simulating $\mathrm{PM}_{2.5}$ over several important regions. Box plots of monthly mean $\mathrm{PM}_{2.5}$ mass concentrations in January 2013 over the NCP, YRD, PRD and CC are displayed in Fig. 13. Over all four regions, the median values of hourly $\mathrm{PM}_{2.5}$ are underestimated in the EMP scenario, in which aerosol feedbacks are excluded. Biases of the median values in the EMP sce-

Figure 13. Observed (black) and simulated (red for the BASE scenario and blue for the EMP scenario) monthly mean $\mathrm{PM}_{2.5}$ mass concentrations in January 2013 over the NCP, YRD, PRD and CC. The dashed lines indicate the maximum and minimum values. The solid lines in the box indicate the median value (the central line), the 25 th and 75 th percentiles.

nario are $-29.1,-16.8,-10.7$, and $-5.3 \%$ over NCP, YRD, $\mathrm{PRD}$, and CC, respectively. By including aerosol feedbacks, the BASE scenario improves the simulation of hourly $\mathrm{PM}_{2.5}$ mass concentrations in two aspects. First, biases of the median values are reduced to $-22.0,-12.0,-6.7$, and $+2.6 \%$ over NCP, YRD, PRD, and CC, respectively. Second, the distribution of the middle $50 \%$ (ranging from 25 th to 75 th percentile) hourly $\mathrm{PM}_{2.5}$ mass concentrations is more consistent with observations than without aerosol feedbacks in the model. We also find a positive feedback for $\mathrm{PM}_{2.5}$; that is, aerosols increase $\mathrm{PM}_{2.5}$ through meteorological and chemical processes.

Overall, in this section we demonstrate the significance of including aerosol feedbacks in the model. Inclusions of aerosol feedbacks in the model reproduce aerosol effects on solar radiation and temperature. Thus, biases of simulated meteorology are reduced. Though the responses of $\mathrm{PM}_{2.5}$ to aerosol feedbacks are complex, the inclusion of aerosol feedbacks improves the model performance to some extent in simulating $\mathrm{PM}_{2.5}$ in winter haze conditions.

\section{Conclusions}

In this work, the fully coupled online WRF-Chem model is applied to investigate aerosol-radiation-cloud feedbacks on 
meteorology and air quality over eastern China in January 2013, the month in which China experienced the most severe haze pollution in history. Three simulation scenarios including different aerosol configurations are undertaken and compared.

The evaluation of the baseline simulation shows that the model captures temporal and vertical variations of meteorological variables, except for overestimating lower atmosphere wind speed which is a common issue for the WRFChem model. The model reproduces spatial distribution of monthly mean $\mathrm{PM}_{2.5}$ mass concentration, with high aerosol concentrations over southern Hebei, Henan, Hubei Province, Sichuan Basin and three big cities (Harbin, Changchun, and Shenyang) in northeastern China. Monthly mean $\mathrm{PM}_{2.5}$ averaged over 71 big cities is underestimated by $15 \%$. The model tends to underestimate $\mathrm{PM}_{2.5}$ at the high ends, which is a common problem for current models in simulating severe haze conditions. Further studies are needed to improve model abilities of simulating high aerosol pollution.

Previous work indicated that the influences on air quality meteorology of aerosol indirect effects are larger than radiative effects, but this was derived under conditions with much lower aerosol loadings than those in our study. In this work we find that under winter haze conditions, aerosol radiative effects (direct effect and semi-direct effects) play a dominant role in modulating downward shortwave flux at the ground surface, lower atmosphere temperature, wind speed, and PBL height. These four meteorological variables are reduced by up to $84.0 \mathrm{~W} \mathrm{~m}^{-2}, 3.2^{\circ} \mathrm{C}, 0.8 \mathrm{~m} \mathrm{~s}^{-1}$, and $268 \mathrm{~m}$, respectively. However, aerosol indirect effects are more important than radiative effects in altering cloud properties and precipitation.

The lower PBL and stabilized lower atmosphere result in increases of near-surface $\mathrm{CO}$ and $\mathrm{SO}_{2}$ concentrations. Higher aerosol loading reduces solar radiation and temperature at the surface, which results in a reduction of $\mathrm{NO}_{2}$ photolysis rate and subsequently a reduction of $\mathrm{O}_{3}$ mixing ratios by up to $6.9 \mathrm{ppb}$. The aerosol feedbacks on $\mathrm{PM}_{2.5}$ concentrations exhibit large spatial variations. Both increases and decreases of $\mathrm{PM}_{2.5}$ are found in the domain. The enhancements of $\mathrm{PM}_{2.5}$ over Henan, Hubei Province, and the Sichuan Basin by up to $17.8 \mu \mathrm{g} \mathrm{m}^{-3}$ are mainly due to a large reduction of PBL height in these areas. The reduction of $\mathrm{PM}_{2.5}$ over the Bohai Sea's surrounding area, northeastern China, and southwestern China result from the transition from air-borne aerosol to cloud-borne aerosol and the activation of a more comprehensive aerosol wet removal module.
The inclusion of aerosol feedback improves the model's ability in simulating downward shortwave radiation and temperature. Simulations of hourly $\mathrm{PM}_{2.5}$ mass concentration distributions over the NCP, YRD, PRD, and CC, are also improved when aerosol feedbacks are included. These indicate the importance of involving aerosol-radiation-cloud interactions in modeling air quality meteorology.

There are a number of limitations in this work. The relatively coarse grid $(27 \mathrm{~km})$, the uncertainty of the emission inventory, and the lack of secondary organic matter all contribute to the uncertainties in simulating aerosols. Also, a 1month simulation could not represent a full view of aerosolradiation-cloud feedbacks. In future, a better understanding can be attained by applying more comprehensive aerosol treatments and a longer time period. Previous studies mainly focus on mechanisms of severe winter haze formation. Different from them, this work demonstrates the importance of aerosol feedbacks on meteorology and air quality during severe winter haze periods. 


\section{Appendix A}

The statistical indices used in this study are defined as follows.

1. Mean bias (MB):

$$
\mathrm{MB}=1 / N \sum_{i=1}^{N}\left(M_{i}-O_{i}\right) .
$$

2. Normalized mean bias (NMB):

$$
\mathrm{NMB}=\frac{\sum_{i=1}^{N}\left(M_{i}-O_{i}\right)}{\sum_{i=1}^{N} O_{i}} \cdot 100 \%
$$

3. Correlation coefficient (Corr. $R$ ):

$$
\text { Corr. } R=\frac{\sum_{i=1}^{N}\left(M_{i}-\bar{M}\right)\left(O_{i}-\bar{O}\right)}{\sqrt{\sum_{i=1}^{N}\left(M_{i}-\bar{M}\right)^{2}} \sqrt{\sum_{i=1}^{N}\left(O_{i}-\bar{O}\right)^{2}}} .
$$

4. Root mean square error (RMSE):

$\mathrm{RMSE}=\sqrt{1 / N \sum_{i=1}^{N}\left(M_{i}-O_{i}\right)^{2}}$,

where $\bar{M}=1 / N \sum_{i=1}^{N} M_{i}, \bar{O}=1 / N \sum_{i=1}^{N} O_{i}$, and $\bar{M}$ and $\bar{O}$ are model result and observation for sample $i$, respectively. $N$ is the number of samples.

5. The Student $t$ statistic:

$t=\frac{\bar{X}_{1}-\bar{X}_{2}}{S_{X_{1} X_{2}} \sqrt{1 / n_{1}+1 / n_{2}}}$,

$S_{X_{1} X_{2}}=\sqrt{\frac{\left(n_{1}-1\right) S_{X_{1}}^{2}+\left(n_{2}-1\right) S_{X_{2}}^{2}}{n_{1}+n_{2}-2}}$.

Here, $S_{X_{1} X_{2}}$ is the grand standard deviation, $S_{X_{1}}^{2}$ and $S_{X_{2}}^{2}$ are the variances of the two samples. 
Acknowledgements. This research was supported by the National Key Basic Research Program of China (2014CB441302), the CAS Strategic Priority Research Program (grant no. XDA05100403), and the Beijing Nova Program (Z121109002512052).

Edited by: X.-Y. Zhang

\section{References}

Ackermann, I. J., Hass, H., Memmesheimer, M., Ebel, A., Binkowski, F. S., and Shankar, U.: Modal aerosol dynamics model for Europe: Development and first applications, Atmos. Environ., 32, 2981-2999, 1998.

Albrecht, B. A.: Aerosols, cloud microphysics, and fractional cloudiness, Science, 245, 1227-1230, 1989.

Bi, J., Huang, J., Hu, Z., Holben, B. N., and Guo, Z.: Investigate the aerosol optical and radiative characteristics of heavy haze episodes in Beijing during January of 2013, J. Geophys. Res.Atmos., 9884-9900, doi:10.1002/2014JD021757, 2014.

Chapman, E. G., Gustafson Jr., W. I., Easter, R. C., Barnard, J. C., Ghan, S. J., Pekour, M. S., and Fast, J. D.: Coupling aerosolcloud-radiative processes in the WRF-Chem model: Investigating the radiative impact of elevated point sources, Atmos. Chem. Phys., 9, 945-964, doi:10.5194/acp-9-945-2009, 2009.

Charlson, R. and Pilat, M.: Climate: The influence of aerosols, J. Appl. Meteorol., 8, 1001-1002, 1969.

Che, H., Xia, X., Zhu, J., Li, Z., Dubovik, O., Holben, B., Goloub, P., Chen, H., Estelles, V., Cuevas-Agulló, E., Blarel, L., Wang, H., Zhao, H., Zhang, X., Wang, Y., Sun, J., Tao, R., Zhang, X., and Shi, G.: Column aerosol optical properties and aerosol radiative forcing during a serious haze-fog month over North China Plain in 2013 based on ground-based sunphotometer measurements, Atmos. Chem. Phys., 14, 2125-2138, doi:10.5194/acp14-2125-2014, 2014.

Chen, F. and Dudhia, J.: Coupling an advanced land surfacehydrology model with the Penn State-NCAR MM5 modeling system - Part I: Model implementation and sensitivity, Mon. Weather Rev., 129, 569-585, 2001.

Cheng, W. Y. Y. and Steenburgh, W. J.: Evaluation of Surface Sensible Weather Forecasts by the WRF and the Eta Models over the Western United States, Weather Forecast., 20, 812-821, doi:10.1175/WAF885.1, 2005.

Chou, M.-D., Suarez, M. J., Ho, C.-H., and Yan, M. M.-H.: Parameterizations for cloud overlapping and shortwave singlescattering properties for use in general circulation and cloud ensemble models, J. Climate, 11, 202-214, doi:10.1175/15200442(1998)011<0202:PFCOAS>2.0.CO;2, 1998.

Emmons, L. K., Walters, S., Hess, P. G., Lamarque, J.-F., Pfister, G. G., Fillmore, D., Granier, C., Guenther, A., Kinnison, D., Laepple, T., Orlando, J., Tie, X., Tyndall, G., Wiedinmyer, C., Baughcum, S. L., and Kloster, S.: Description and evaluation of the Model for Ozone and Related chemical Tracers, version 4 (MOZART-4), Geosci. Model Dev., 3, 43-67, doi:10.5194/gmd3-43-2010, 2010.

Fan, J., Zhang, R., Tao, W. K., and Mohr, K. I.: Effects of aerosol optical properties on deep convective clouds and radiative forcing, J. Geophys. Res.-Atmos., 113, D08209, doi:10.1029/2007JD009257, 2008.
Fast, J. D., Gustafson, W. I., Easter, R. C., Zaveri, R. A., Barnard, J. C., Chapman, E. G., Grell, G. A., and Peckham, S. E.: Evolution of ozone, particulates, and aerosol direct radiative forcing in the vicinity of Houston using a fully coupled meteorology-chemistry-aerosol model, J. Geophys. Res.-Atmos., 111, D21305, doi:10.1029/2005JD006721, 2006.

Forkel, R., Werhahn, J., Hansen, A. B., McKeen, S., Peckham, S., Grell, G., and Suppan, P.: Effect of aerosol-radiation feedback on regional air quality-a case study with WRF/Chem, Atmos. Environ., 53, 202-211, 2012.

Forkel, R., Balzarini, A., Baró, R., Bianconi, R., Curci, G., JiménezGuerrero, P., Hirtl, M., Honzak, L., Lorenz, C., Im, U., Pérez, J. L., Pirovano, G., San José, R., Tuccella, P., Werhahn, J., and Žabkar, R.: Analysis of the WRF-Chem contributions to AQMEII phase2 with respect to aerosol radiative feedbacks on meteorology and pollutant distributions, Atmos. Environ., doi:10.1016/j.atmosenv.2014.10.056, online first, 2014.

Grell, G. and Baklanov, A.: Integrated modeling for forecasting weather and air quality: A call for fully coupled approaches, Atmos. Environ., 45, 6845-6851, doi:10.1016/j.atmosenv.2011.01.017, 2011.

Grell, G. A. and Dévényi, D.: A generalized approach to parameterizing convection combining ensemble and data assimilation techniques, Geophys. Res. Lett., 29, 38-31-38-34, 2002.

Grell, G. A., Peckham, S. E., Schmitz, R., McKeen, S. A., Frost, G., Skamarock, W. C., and Eder, B.: Fully coupled "online" chemistry within the WRF model, Atmos. Environ., 39, 6957-6975, 2005.

Guenther, A., Karl, T., Harley, P., Wiedinmyer, C., Palmer, P. I., and Geron, C.: Estimates of global terrestrial isoprene emissions using MEGAN (Model of Emissions of Gases and Aerosols from Nature), Atmos. Chem. Phys., 6, 3181-3210, doi:10.5194/acp-63181-2006, 2006.

Gustafson, W. I., Chapman, E. G., Ghan, S. J., Easter, R. C., and Fast, J. D.: Impact on modeled cloud characteristics due to simplified treatment of uniform cloud condensation nuclei during NEAQS 2004, Geophys. Res. Lett., 34, L19809, doi:10.1029/2007GL030021, 2007.

Hansen, J., Sato, M., and Ruedy, R.: Radiative forcing and climate response, J. Geophys. Res.-Atmos., 102, 6831-6864, 1997.

Harris, E., Sinha, B., van Pinxteren, D., Tilgner, A., Fomba, K. W., Schneider, J., Roth, A., Gnauk, T., Fahlbusch, B., and Mertes, S.: Enhanced role of transition metal ion catalysis during in-cloud oxidation of $\mathrm{SO}_{2}$, Science, 340, 727-730, 2013.

Hong, S.-Y., Noh, Y., and Dudhia, J.: A new vertical diffusion package with an explicit treatment of entrainment processes, Mon. Weather Rev., 134, 2318-2341, doi:10.1175/MWR3199.1, 2006.

Huang, K., Zhuang, G., Wang, Q., Fu, J. S., Lin, Y., Liu, T., Han, L., and Deng, C.: Extreme haze pollution in Beijing during January 2013: chemical characteristics, formation mechanism and role of fog processing, Atmos. Chem. Phys. Discuss., 14, 7517-7556, doi:10.5194/acpd-14-7517-2014, 2014.

Huang, R. J., Zhang, Y., Bozzetti, C., Ho, K. F., Cao, J. J., Han, Y., Daellenbach, K. R., Slowik, J. G., Platt, S. M., Canonaco, F., Zotter, P., Wolf, R., Pieber, S. M., Bruns, E. A., Crippa, M., Ciarelli, G., Piazzalunga, A., Schwikowski, M., Abbaszade, G., SchnelleKreis, J., Zimmermann, R., An, Z., Szidat, S., Baltensperger, U., Haddad, I. E., and Prevot, A. S. H.: High secondary aerosol con- 
tribution to particulate pollution during haze events in China, Nature, 514, 218-222, doi:10.1038/nature13774, 2014.

Jiang, F., Liu, Q., Huang, X., Wang, T., Zhuang, B., and Xie, M.: Regional modeling of secondary organic aerosol over China using WRF/Chem, J. Aerosol Sci., 43, 57-73, doi:10.1016/j.jaerosci.2011.09.003, 2012.

Kong, X., Forkel, R., Sokhi, R. S., Suppan, P., Baklanov, A., Gauss, M., Brunner, D., Barò, R., Balzarini, A., Chemel, C., Curci, G., Jiménez-Guerrero, P., Hirtl, M., Honzak, L., Im, U., Pérez, J. L., Pirovano, G., San Jose, R., Schlünzen, K. H., Tsegas, G., Tuccella, P., Werhahn, J., Žabkar, R., and Galmarini, S.: Analysis of meteorology-chemistry interactions during air pollution episodes using online coupled models within AQMEII phase2, Atmos. Environ., doi:10.1016/j.atmosenv.2014.09.020, online first, 2014.

Lin, Y.-L., Farley, R. D., and Orville, H. D.: Bulk parameterization of the snow field in a cloud model, J. Clim. Appl. Meteorol., 22, 1065-1092, 1983.

Liu, X.-H., Zhang, Y., Cheng, S.-H., Xing, J., Zhang, Q., Streets, D. G., Jang, C., Wang, W.-X., and Hao, J.-M.: Understanding of regional air pollution over China using CMAQ, part I performance evaluation and seasonal variation, Atmos. Environ., 44, 2415-2426, 2010.

Makar, P. A., Gong, W., Milbrandt, J., Hogrefe, C., Zhang, Y., Curci, G., Žabkar, R., Im, U., Balzarini, A., Baró, R., Bianconi, R., Cheung, P., Forkel, R., Gravel, S., Hirtl, M., Honzak, L., Hou, A., Jiménez-Guerrero, P., Langer, M., Moran, M. D., Pabla, B., Pérez, J. L., Pirovano, G., San José, R., Tuccella, P., Werhahn, J., Zhang, J., and Galmarini, S.: Feedbacks between Air Pollution and Weather - Part 1: Effects on Weather, Atmos. Environ., doi:10.1016/j.atmosenv.2014.12.003, online first, 2014a.

Makar, P. A., Gong, W., Hogrefe, C., Zhang, Y., Curci, G., Žabkar, R., Milbrandt, J., Im, U., Balzarini, A., Baró, R., Bianconi, R., Cheung, P., Forkel, R., Gravel, S., Hirtl, M., Honzak, L., Hou, A., Jiménez-Guerrero, P., Langer, M., Moran, M. D., Pabla, B., Pérez, J. L., Pirovano, G., San José, R., Tuccella, P., Werhahn, J., Zhang, J., and Galmarini, S.: Feedbacks between air pollution and weather - Part 2: Effects on chemistry, Atmospheric Environment, doi:10.1016/j.atmosenv.2014.10.021, online first, 2014b.

Matsui, H., Koike, M., Kondo, Y., Takegawa, N., Kita, K., Miyazaki, Y., Hu, M., Chang, S. Y., Blake, D. R., Fast, J. D., Zaveri, R. A., Streets, D. G., Zhang, Q., and Zhu, T.: Spatial and temporal variations of aerosols around Beijing in summer 2006: Model evaluation and source apportionment, J. Geophys. Res.Atmos., 114, D00G13, doi:10.1029/2008jd010906, 2009.

Mlawer, E. J., Taubman, S. J., Brown, P. D., Iacono, M. J., and Clough, S. A.: Radiative transfer for inhomogeneous atmospheres: RRTM, a validated correlated-k model for the longwave, J. Geophys. Res.-Atmos., 102, 16663-16682, 1997.

Molders, N., Tran, H. N. Q., Cahill, C. F., Leelasakultum, K., and Tran, T. T.: Assessment of WRF/Chem PM2.5 forecasts using mobile and fixed location data from the Fairbanks, Alaska winter 2008/09 field campaign, Atmos. Pollut. Res., 3, 180-191, doi:10.5094/apr.2012.018, 2012.

Morrison, H., Thompson, G., and Tatarskii, V.: Impact of cloud microphysics on the development of trailing stratiform precipitation in a simulated squall line: Comparison of one-and two-moment schemes, Mon. Weather Rev., 137, 991-1007, doi:10.1175/2008MWR2556.1, 2009.

Rosenfeld, D., Lohmann, U., Raga, G. B., O’Dowd, C. D., Kulmala, M., Fuzzi, S., Reissell, A., and Andreae, M. O.: Flood or drought: how do aerosols affect precipitation?, Science, 321, 1309-1313, 2008.

Schell, B., Ackermann, I. J., Hass, H., Binkowski, F. S., and Ebel, A.: Modeling the formation of secondary organic aerosol within a comprehensive air quality model system, J. Geophys. Res.Atmos., 106, 28275-28293, 2001.

Sun, Y., Jiang, Q., Wang, Z., Fu, P., Li, J., Yang, T., and Yin, Y.: Investigation of the sources and evolution processes of severe haze pollution in Beijing in January 2013, J. Geophys. Res.-Atmos., 119, 4380-4398, doi:10.1002/2014JD021641, 2014.

Tao, W.-K., Chen, J.-P., Li, Z., Wang, C., and Zhang, C.: Impact of aerosols on convective clouds and precipitation, Rev. Geophys., 50, RG2001, doi:10.1029/2011RG000369, 2012.

Tuccella, P., Curci, G., Visconti, G., Bessagnet, B., Menut, L., and Park, R. J.: Modeling of gas and aerosol with WRF/Chem over Europe: Evaluation and sensitivity study, J. Geophys. Res.Atmos., 117, D03303, doi:10.1029/2011jd016302, 2012.

Twomey, S.: The influence of pollution on the shortwave albedo of clouds, J. Atmos. Sci., 34, 1149-1152, 1977.

Wang, H., Zhang, X., Gong, S., and Xue, M.: The simulation study of the interaction between aerosols and heavy air pollution weather in East China, AIP Conf. Proc., 1527, 499-502, doi:10.1063/1.4803314, 2013.

Wang, L. T., Wei, Z., Yang, J., Zhang, Y., Zhang, F. F., Su, J., Meng, C. C., and Zhang, Q.: The 2013 severe haze over southern Hebei, China: model evaluation, source apportionment, and policy implications, Atmos. Chem. Phys., 14, 3151-3173, doi:10.5194/acp-14-3151-2014, 2014.

Wang, Y., and Zhou, L.: Observed trends in extreme precipitation events in China during 1961-2001 and the associated changes in large-scale circulation, Geophys. Res. Lett., 32, L09707, doi:10.1029/2005GL022574, 2005.

Wang, Y. S., Yao, L., Wang, L., Liu, Z., Ji, D., Tang, G., Zhang, J., Sun, Y., Hu, B., and Xin, J.: Mechanism for the formation of the January 2013 heavy haze pollution episode over central and eastern China, Sci. China Ser. D, 1-12, 2014.

Wang, Y. X., Zhang, Q., Jiang, J., Zhou, W., Wang, B., He, K., Duan, F., Zhang, Q., Philip, S., and Xie, Y.: Enhanced sulfate formation during China's severe winter haze episode in Jan 2013 missing from current models, J. Geophys. Res.-Atmos., 119, 1042510440, doi:10.1002/2013JD021426, 2014.

Wang, Z. F., Li, J., Wang, Z., Yang, W., Tang, X., Ge, B., Yan, P., Zhu, L., Chen, X., and Chen, H.: Modeling study of regional severe hazes over mid-eastern China in January 2013 and its implications on pollution prevention and control, Sci. China Ser. D, 57, 3-13, 2014.

Yahya, K., Wang, K., Gudoshava, M., Glotfelty, T., and Zhang, Y.: Application of WRF/Chem over North America under the AQMEII Phase 2 - Part I: Comprehensive evaluation of 2006 simulation, Atmos. Environ. doi:10.1016/j.atmosenv.2014.08.063, online first, 2014.

Yang, Q., W. I. Gustafson Jr., Fast, J. D., Wang, H., Easter, R. C., Morrison, H., Lee, Y.-N., Chapman, E. G., Spak, S. N., and Mena-Carrasco, M. A.: Assessing regional scale predictions of aerosols, marine stratocumulus, and their interactions dur- 
ing VOCALS-REx using WRF-Chem, Atmos. Chem. Phys., 11, 11951-11975, doi:10.5194/acp-11-11951-2011, 2011.

Zaveri, R. A. and Peters, L. K.: A new lumped structure photochemical mechanism for large-scale applications, J. Geophys. Res.Atmos., 104, 30387-30415, 1999.

Zaveri, R. A., Easter, R. C., Fast, J. D., and Peters, L. K.: Model for simulating aerosol interactions and chemistry (MOSAIC), J. Geophys. Res.-Atmos., 113, D13204, doi:10.1029/2007JD008782, 2008.

Zhang, J. K., Sun, Y., Liu, Z. R., Ji, D. S., Hu, B., Liu, Q., and Wang, Y. S.: Characterization of submicron aerosols during a month of serious pollution in Beijing, 2013, Atmos. Chem. Phys., 14, 2887-2903, doi:10.5194/acp-14-2887-2014, 2014.

Zhang, Y., Wen, X.-Y., and Jang, C.: Simulating chemistry-aerosolcloud-radiation-climate feedbacks over the continental US using the online-coupled Weather Research Forecasting Model with chemistry (WRF/Chem), Atmos. Environ., 44, 3568-3582, 2010.

Zhang, Y., Bocquet, M., Mallet, V., Seigneur, C., and Baklanov, A.: Real-time air quality forecasting - Part I: History, techniques, and current status, Atmos. Environ., 60, 632-655, doi:10.1016/j.atmosenv.2012.06.031, 2012.
Zhang, Y., Zhang, X., Cai, C., Wang, K., and Wang, L.: Studying Aerosol-Cloud-Climate Interactions over East Asia Using WRF/Chem, in: Air Pollution Modeling and its Application XXIII, Springer International Publishing, Switzerland, 61-66, 2014.

Zhao, C., Liu, X., Ruby Leung, L., and Hagos, S.: Radiative impact of mineral dust on monsoon precipitation variability over West Africa, Atmos. Chem. Phys., 11, 1879-1893, doi:10.5194/acp11-1879-2011, 2011.

Zhao, C., Liu, X., and Leung, L. R.: Impact of the Desert dust on the summer monsoon system over Southwestern North America, Atmos. Chem. Phys., 12, 3717-3731, doi:10.5194/acp-12-37172012, 2012.

Zhou, G., Yang, F., Geng, F., Xu, J., Yang, X., and Tie, X.: Measuring and Modeling Aerosol: Relationship with Haze Events in Shanghai, China, Aerosol. Air Qual. Res., 14, 783-792, 2014. 